\title{
Chenopodium ucrainicum (Chenopodiaceae / Amaranthaceae sensu APG), a new diploid species: a morphological description and pictorial guide
}

\author{
Sergei L. MOSYAKIN ${ }^{1}$, Bohumil MANDÁK ${ }^{2,3}$ \\ ${ }^{1}$ M.G. Kholodny Institute of Botany, National Academy of Sciences of Ukraine \\ 2 Tereschenkivska Str., Kyiv 01601, Ukraine \\ s_mosyakin@hotmail.com \\ ${ }^{2}$ Faculty of Environmental Sciences, Czech University of Life Sciences Prague \\ 129 Kamýcká, Praha 6 - Suchdol 165 21, Czech Republic \\ mandak@fzp.czu.cz \\ ${ }^{3}$ Institute of Botany, Czech Academy of Sciences \\ 1 Zámek, Průhonice 252 43, Czech Republic \\ bohumil.mandak@ibot.cas.cz
}

Mosyakin S.L., Mandák B. 2020. Chenopodium ucrainicum (Chenopodiaceae / Amaranthaceae sensu APG), a new diploid species: a morphological description and pictorial guide. Ukrainian Botanical Journal, 77(4): $237-248$.

\begin{abstract}
A morphological description is provided for Chenopodium ucrainicum Mosyakin \& Mandák (Chenopodiaceae / Amaranthaceae sensu APG), a new species allied to C. suecicum and C. ficifolium. At present this new species is reliably known from several localities in Ukraine (three areas in Kyiv city, one in Kyiv Region, one in Rivne Region), but it is probably more widespread, or could be even alien in Eastern Europe. Comparison of our plants with other taxa [such as C. suecicum (incl. C. neumanii, etc.), C. ficifolium, several morphotypes of $C$. album, as well as plants known as C. borbasii, $C$. missouriense (sensu stricto and sensu auct. europ.), C. lobodontum, etc.], demonstrated that C. ucrainicum is morphologically different from all these known and named taxa. It is also a late-flowering and late-fruiting species: in Kyiv fruits/seeds normally develop during late September - early November. This significantly reduces the possibility of gene flow and therefore hybridization with closely related diploid species, like $C$. ficifolium or C. suecicum, which usually flower and produce fruits earlier, mainly in July-August to early September. It also suggests that the new taxon is well isolated from its congeners and indeed represents a good species, not just one of weakly differentiated morphotypes that are so numerous in the C. album aggregate. To help researchers in identifying C. ucrainicum in the field and in herbaria, original illustrations are provided in the article and the Electronic Supplement. These illustrations include scanned images of the holotype (one specimen representing parts of one plant mounted on four herbarium sheets), field photographs showing plants and their parts at different stages of their development, and photomicrographs of fruits/seeds. Cytological and molecular data of the research team of B. Mandák (research in progress, detailed results to be published separately) demonstrated that C. ucrainicum is a B-genome diploid indeed related to C. suecicum and C. ficifolium.
\end{abstract}

Keywords: Chenopodiaceae, Chenopodium, diploid, herbarium, nomenclature, taxonomy, type specimen, Ukraine

Supplementary Material. Electronic Supplement (Figures E1-E20, e1-e10) is available in the online version of this article at: https://ukrbotj.co.ua/archive/77/4/237 
Мосякін С.Л. ${ }^{1}$, Мандак Б. ${ }^{2,3}$ 2020. Новий диплоїдний вид Chenopodium ucrainicum (Chenopodiaceae / Amaranthaceae sensu APG): морфологічний опис та ілюстрований огляд. Украӥнський ботанічний журнал, 77(4): 237-248.

${ }^{1}$ Інститут ботаніки ім. М.Г. Холодного НАН України

вул. Терещенківська 2, Київ 01601, Україна

${ }^{2}$ Факультет наук про довкілля, Чеський сільськогосподарський університет у Празі

Прага 6 - Сухдол 165 21, Чеська Республіка

mandak@fzp.czu.cz

${ }^{3}$ Інститут ботаніки Чеської академії наук

Пругоніце 252 43, Чеська Республіка

bohumil.mandak@ibot.cas.cz

Реферат. Наведено морфологічний опис нового виду Chenopodium ucrainicum Mosyakin \& Mandák (Chenopodiaceae / Amaranthaceae sensu APG), який споріднений з C. suecicum та C. ficifolium. На цей час новий вид достовірно відомий 3 декількох локалітетів в Україні (три місцезнаходження у м. Київ, одне - у Київській області, одне - у Рівненській області), але він, очевидно, розповсюджений ширше, або ж навіть може виявитися адвентивним у Східній Європі. Порівняння наших рослин з іншими таксонами, наприклад, C. suecicum (incl. C. neumanii, etc.), C. ficifolium, декількома морфотипами $C$. album, а також з рослинами, відомими під назвами $C$. borbasii, C. missouriense (sensu stricto та sensu auct. europ.), C. lobodontum та деякими іншими, показало, що C. исrainicum морфологічно відрізняється від усіх цих відомих таксонів, що мають назви видового рангу. Новий вид характеризується пізнім цвітінням та плодоношенням: у Києві плодоношення зазвичай триває 3 другої половини вересня до початку листопада. Така фенологічна особливість значно зменшує можливості обміну генетичним матеріалом через гібридизацію з близько спорідненими диплоїдними видами, зокрема C. ficifolium або C. suecicum, які зазвичай квітують та утворюють плоди раніше, у липні-серпні (до середини вересня). Ця особливість також вказує на те, що новий таксон добре відокремлений від інших представників роду і дійсно є справжнім видом, а не просто ще одним з численних слабо диференційованих морфотипів групи C. album. Для того, щоб дослідники мали змогу визначити C. ucrainicum у природі та гербарії, у статті та її електронному додатку наведені оригінальні ілюстрації, а саме: скановані зображення голотипу (один зразок, що містить частини однієї рослини, змонтовані на чотирьох гербарних аркушах), натурні фотографії рослин та їхніх частин на різних стадіях розвитку, а також мікрофотографії плодів та насінин. Цитологічні та молекулярні дані дослідницької групи Б. Мандака (дослідження тривають, детальні результати будуть опубліковані окремо) показали, що C. ucrainicum є В-геномним диплоїдом, спорідненим з C. suecicum та C. ficifolium.

Keywords: Chenopodiaceae, Chenopodium, гербарій, діплоїд, номенклатура, таксономія, типовий зразок, Україна

\section{Introduction}

A new general scheme of allopolyploid evolution and speciation in the genus Chenopodium L. (in its restricted generic circumscription: see Fuentes-Bazan et al., 2012) based on hybridization of "primary" diploid taxa and subsequent polyploidization emphasized the role played by diploid species in the evolutionary processes (Mandák et al., 2018; see also Mandák et al., 2012; Walsh et al., 2015; Krak et al., 2016, etc.). A surprisingly simple scheme of polyploid species formation within the C. album aggregate was discovered (see Mandák et al., 2018) and it explained general taxonomic patterns in this group that contains economically important crop species (such as the pseudocereal C. quinoa Willd. and its relatives in the Americas and C. giganteum D.Don and some other Asian taxa used mainly as leaf vegetables) and noxious weeds (various taxa of the C. album $\mathrm{L}$. aggregate). Because of that, discovery, inventory and proper identification of diploid taxa of Chenopodium sensu stricto is of considerable interest not only for better understanding of the evolutionary and taxonomic patterns in the group, but also potentially for genetic improvement of crop species and cultivars, for which various diploids may serve as promising sources of useful genetic traits.

Here we report a new species that was collected and observed in Ukraine by the first author since 1989 . Special observations in the field (by Sergei Mosyakin), and recently also in cultivation, complemented by molecular and karyological studies (by Bohumil Mandák and his team; to be published separately), convincingly demonstrated that it is a distinct species allied to C. suecicum Murr and C. ficifolium Sm. Despite extensive studies of herbarium material (physical specimens at various herbaria and scanned images available online) and literature, we were unable to find any earlier described species matching our plants morphologically or otherwise (see comments below).

We thus provide here a formal morphological description of the new species. To help researchers in identifying the newly described species in the field and in herbaria, original illustrations are provided in the article and in the Electronic Supplement. These illustrations include scanned images of the holotype, field photographs 
showing plants and close-ups of their parts at different stages of their development, and photomicrographs of fruits/seeds.

Herbarium acronyms used below follow Index Herbariorum (Thiers, 2008-onward).

\section{Description of the new species}

\section{Chenopodium ucrainicum Mosyakin \& Mandák, sp. nov.}

Type: UKRAINE, Kyiv (Kiev), Shevchenkivsky District, Tatarka historical neighborhood, Baggovutivska Street, near (behind) the Promenada Mall, shady areas under trees on slopes with ruderal vegetation. Latitude 50.470357 N, Longitude 30.479655 E. Co-occurring species: Ballota nigra s.l., Chelidonium majus L., Urtica dioica L., Polygonum aviculare L. aggr. (along paths), Erigeron annuus (L.) Pers., Atriplex sagittata Borkh. (occasional on drier and more sunny slopes), etc. Cooccurring species of Chenopodium: C. album L. s.l. (incl. morphologically corresponding to "ssp. fallax" Aellen), C. betaceum Andrz. (C. "strictum" auct. non Roth), C. opulifolium Schrad. ex Koch \& Ziz (occasional, on drier, open, and more sunny spots). 02 October 2019. Leg. \& Det.: Sergei L. Mosyakin. Holotype: KW, one specimen containing parts of one individual plant mounted of four herbarium sheets, with four barcodes (see Art. 8.2 and 8.3 of the ICN: Turland et al., 2018): KW001003108, KW001003109, KW001003110, and KW001003111 (see Fig. 1-4). Isotypes (currently at $\mathrm{KW}$, to be distributed to several other herbaria): KW001003112-KW001003115 (one specimen on four sheets), KW001003116-KW001003118 (one specimen on three sheets), KW001003119 \& KW001003120 (one specimen on two sheets), KW001003121-KW001003123 (one specimen on three sheets), KW001003124 \& KW001003125 (one specimen on two sheets), and other specimens with the same label information matching the label of the holotype (see above). E20.

Illustrations: Electronic supplement, Figures E1-

Plants annual, light green or yellowish green, in October-November sometimes becoming darker green, sparsely covered with whitish (on young leaves often golden or golden-pinkish) mealy indumentum, becoming subglabrous at maturity. Main stem erect, 10-110 (-130) $\mathrm{cm}$ tall, normally branched above the base, less commonly with branches almost near the base, or rarely (in underdeveloped plants growing in dense stands) branched only in the inflorescence. Stem and branches striate, with alternating dark green and light green stripes, at nodes becoming reddish or with beet-red spots (Fig. E13, E14). Lower and middle primary branches usually spreading almost horizontally, forming with the main stem an angle almost approaching $90^{\circ}$ (occasionally lower branches, if close to the plant base, arcuate or ascending); upper branches spreading, ascending to suberect, at maturity in inflorescence with distal ends often nodding, usually thin and fragile (thicker in plants growing in open places). Leaves (when fully developed) normally long-petiolate, with petiole often almost as long as lamina, or shorter than lamina in upper leaves and longer than lamina in lower leaves; leaf blades usually thin and soft (somewhat thicker in plants growing in open places), rather variable in shape (in particular, depending on vegetation phases and growing conditions) (Fig. E3-E11, E14, E16). Lower and middle cauline leaves with leaf blades (3-) 4-8 (-10) cm long and (1-) 2-4 (-6) cm wide, more or less distinctly trilobate (or sometimes almost ovate in outline), lateral lobes located in basal $1 / 3$ or $1 / 2$ of leaf blade; base cuneate to broadly cuneate; apex obtuse to subacute; margins undulate, crenate or obtusely dentate. Upper cauline leaves becoming gradually smaller on the plant upward, indistinctly trilobate or subhastate to ovate-lanceolate or lanceolate, apex mainly subacute, margin with a few teeth to subentire or entire. Young leaves with whitish or often golden or goldenpinkish mealy indumentum above (Fig. E1, E2, E5). Inflorescence usually thin and lax (Fig. E11-E13), partial inflorescences moniliform or nearly so, with flowers arranged in small few-flowered remote glomerules, some flowers solitary (Fig. E13, E17, E18). Perianth segments (tepals) 5, green to yellowish-green, distal ("back") side more or less distinctly keeled, at least in some flowers (Fig. E18); tepals normally only partly cover fruits at maturity. Fruits usually ca. (0.9-) $1.0-1.3(-1.4) \mathrm{mm}$ in diameter; pericarp not easily removed when rubbed, in dry state with distinct sculpture (Fig. E20A); seeds rather variable in color (heterospermy): whitish, ivory- or yellowish-white when immature, most of them becoming reddish-brown, brown or almost black at maturity (Fig. E19), equatorially rather distinctly keeled; testa almost smooth, with shallow depressions and grooves extended to equatorial zone (Fig. E20B). Seeds horizontal, embryo circular. B-genome diploids with $2 n=18$.

Distribution: At present the species is reliably reported only from Ukraine, where its localities are known in the city of Kyiv (three sites, numerous specimens in KW), Kyiv Region (Vasylkiv District, Hrebinky, occurring in 


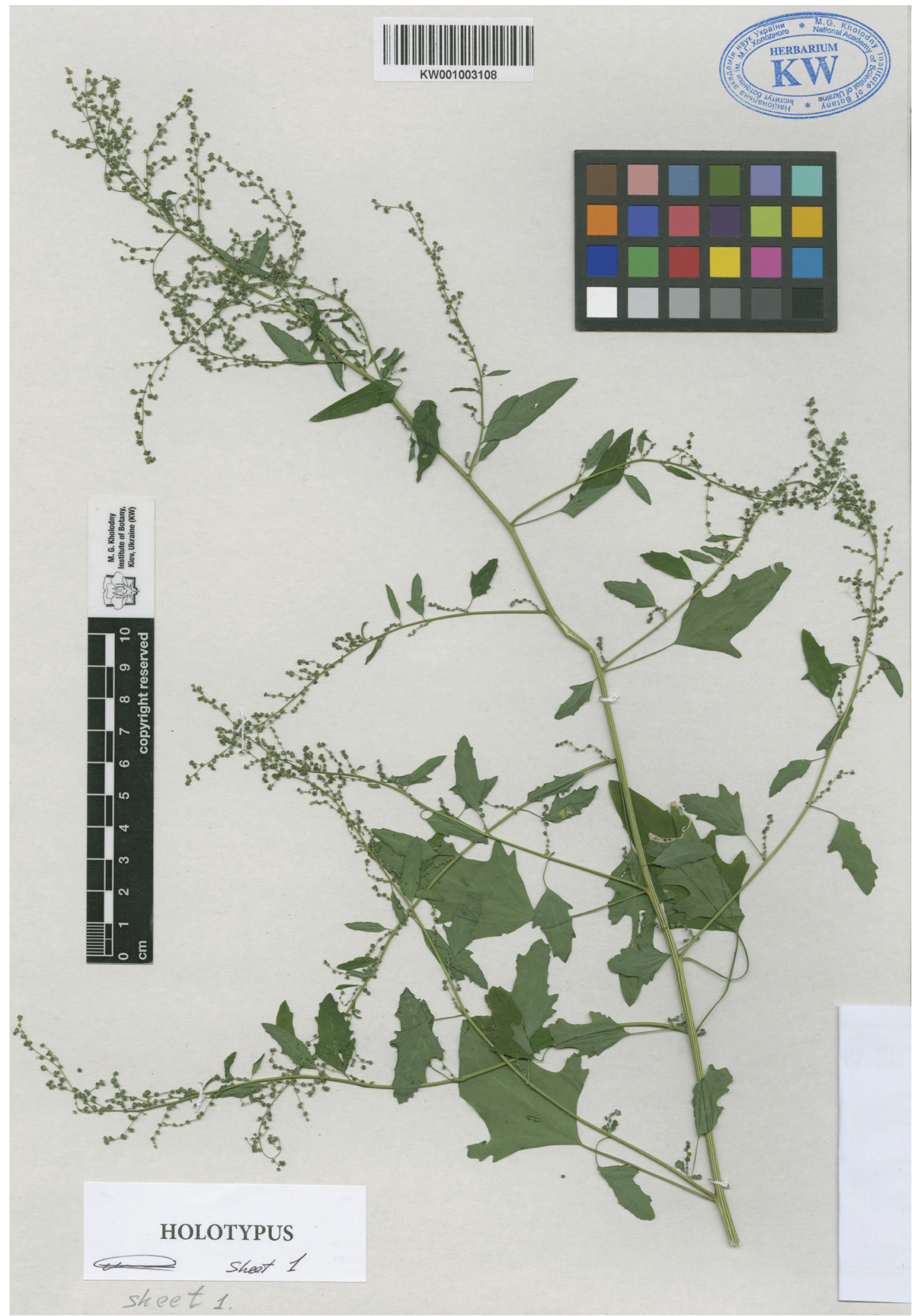

Fig. 1. Holotype of Chenopodium ucrainicum, KW001003108, sheet 1 (label folded to show plant parts) 


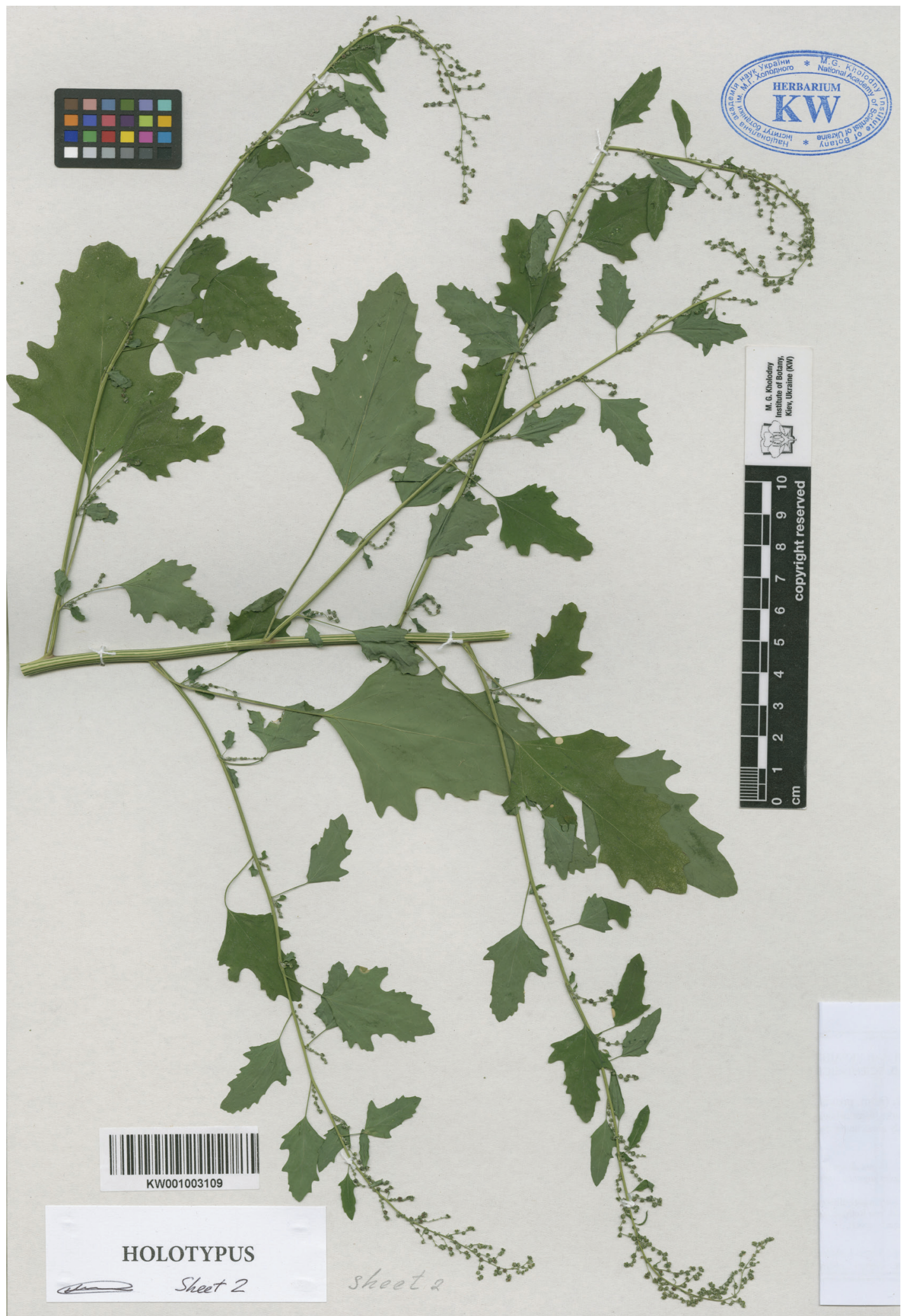

Fig. 2. Holotype of Chenopodium ucrainicum, KW001003109, sheet 2 (label folded to show plant parts) 


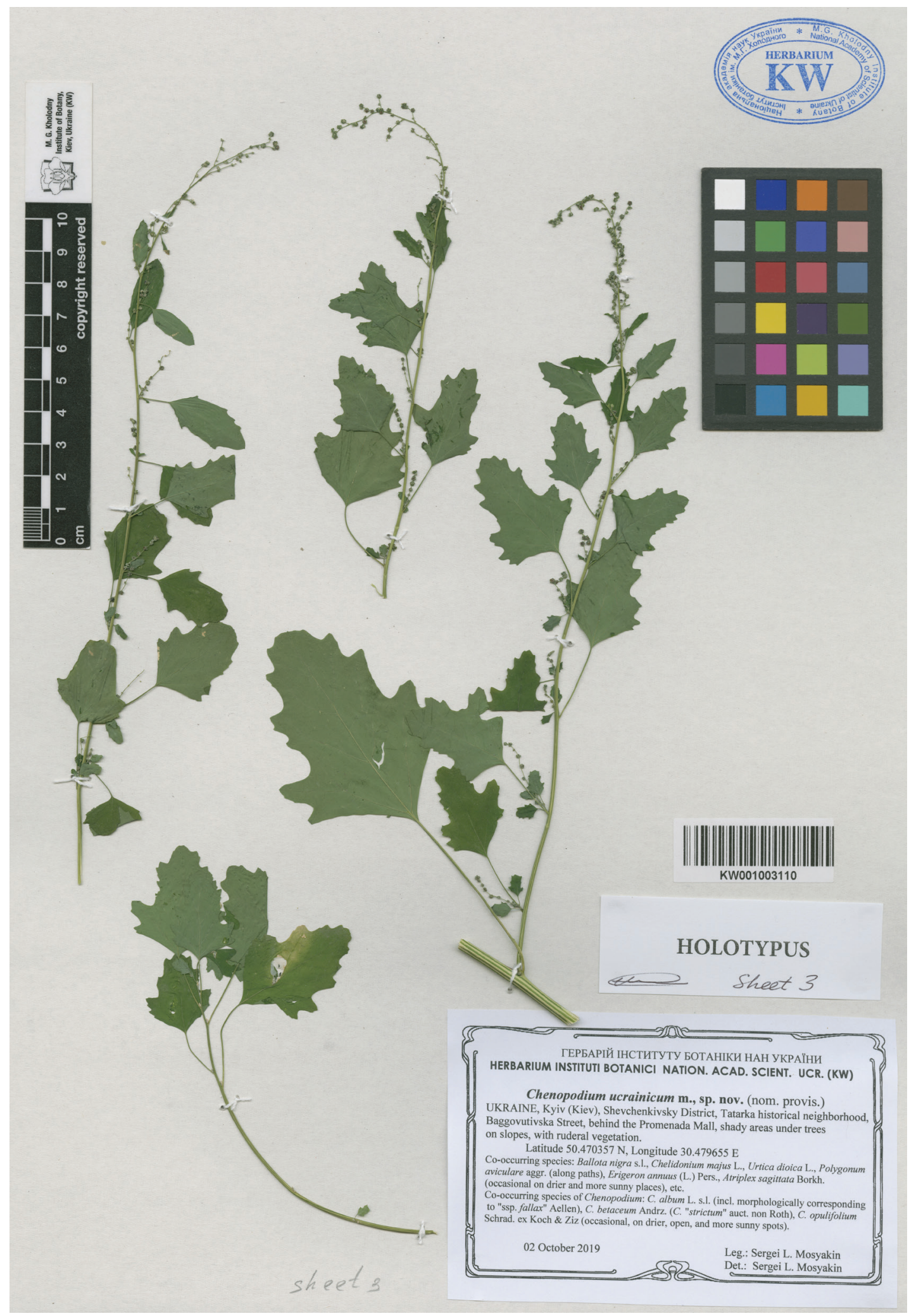

Fig. 3. Holotype of Chenopodium ucrainicum, KW001003110, sheet 3 


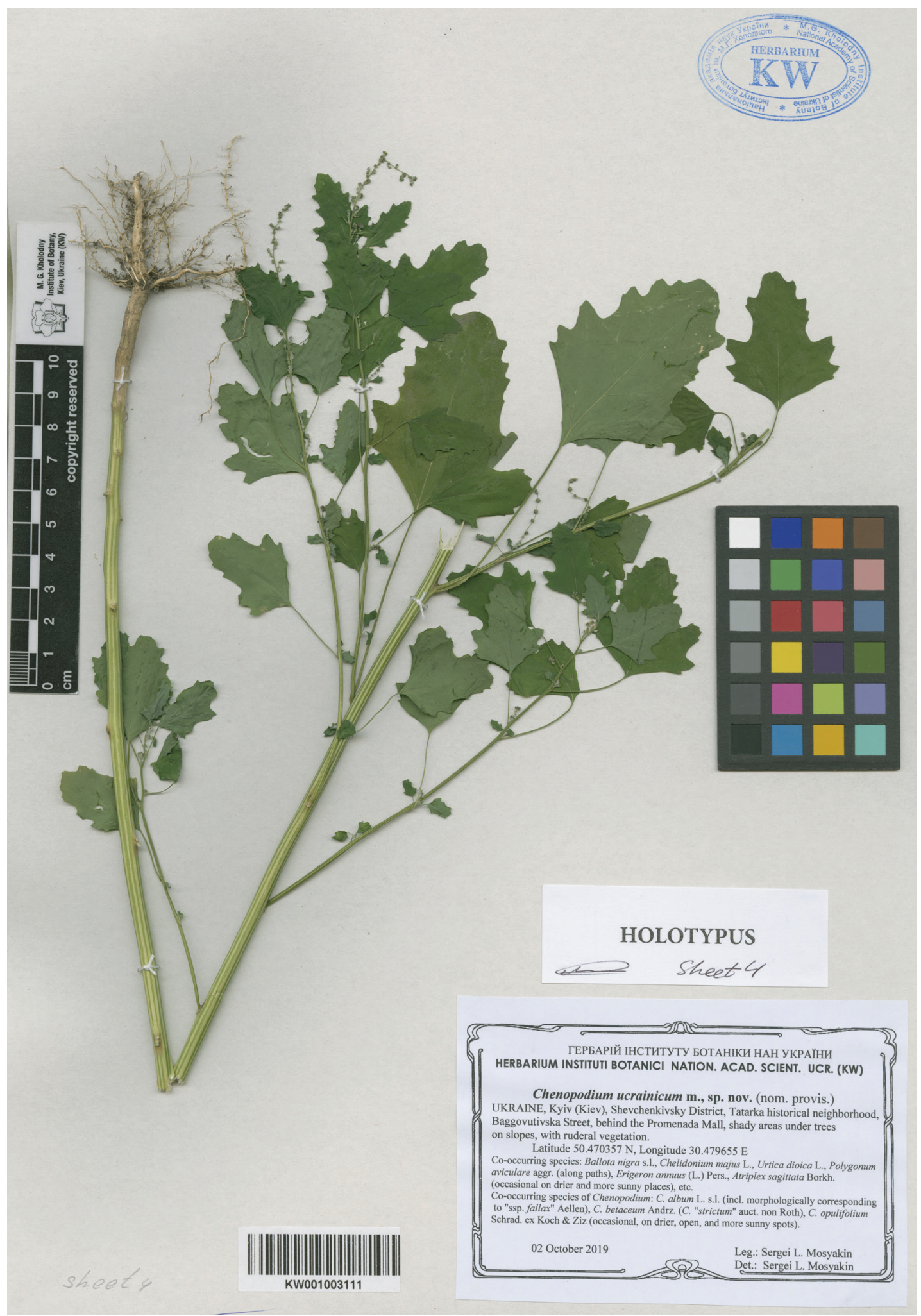

Fig. 4. Holotype of Chenopodium ucrainicum, KW001003111, sheet 4

Украӥнський ботанічний журнал, 2020, 77(4) 
several localities in the area, numerous specimens in $\mathrm{KW}$ ), and in the northwestern part of Ukraine in Ostrog, Rivne Region (a young plant collected by L.M. Gubar, 14 July 2003, KW, No. 060233). Preliminary data (in particular, some images available online) also indicate that it may occur in Ukraine in Ternopil Region (western part of the country), and probably also locally in Central and/or Western Europe. However, its presence there is not yet confirmed. The pattern of distribution of the species in Ukraine and its habitats there may even indicate that C. ucrainicum is actually alien in Europe, but in that case its primary range is unknown. The peculiar late-season development and the leaf shape somewhat similar to that of some eastern and southeastern forms of C. ficifolium may suggest some links of $C$. ucrainicum with plants occurring in East and South-East Asia, but currently there is no confirmation to that suggestion.

Habitats and co-occurring species: Judging from the currently available data, C. ucrainicum grows in Ukraine in various ruderal habitats, but it evidently prefers shady areas under the canopy of trees in parks, also among shrubs, along roadsides and fences, etc. Usually it occurs as groups or in dense stands (Fig. E3, E4, E7, E12, E15), often together with some other species of Chenopodium. The co-occurring species most commonly include tetraploid C. betaceum Andrz. (C. strictum sensu auct., non Roth: see Mosyakin, 2017), with which it may grow side by side (see Fig. E9), and various morphotypes of hexaploid C. album (co-occurring in all known localities); less commonly also diploids C. ficifolium and $C$. suecicum and hexaploid C. opulifolium Schrad. ex Koch \& Ziz. However, preferred micro-habitats of the mentioned species are usually somewhat different. Preliminary results of field observations of Sergei Mosyakin also indicate that C. ucrainicum may probably (rarely?) form spontaneous hybrids with some other co-occurring species of Chenopodium (diploids and/ or tetraploids?), thus probably contributing to the morphological and genetic diversity of hexaploids currently collectively known as C. album sensu lato. However, these observations should be critically tested using appropriate experimental and molecular methods.

Phenology: Chenopodium ucrainicum is a lateflowering (September to mid-October) and late-fruiting (late September to mid-November) species. In Kyiv the species was observed during several years in fruit and still with green foliage even in the beginning of November, until mid-November, when freezing temperatures (below $0^{\circ} \mathrm{C}$ ) were already registered at night (see Fig. E11-E17). At that time the co-occurring plants of $C$. betaceum and C. opulifolium in locus classicus of C. ucrainicum (see above) were already leafless and dry. The late development of $C$. ucrainicum probably contributed to its "invisibility" to researchers because in temperate regions of Europe botanists rarely collect specimens of Chenopodium in October and November, when most of other species of the genus are already leafless and hardly identifiable. Also, the unusually late flowering period of C. ucrainicum significantly reduces the possibility of gene flow and therefore hybridization with closely related diploid species, like $C$. ficifolium or $C$. suecicum, which usually flower and start to produce fruits earlier, mainly in July-August to early September. It also suggests that the new taxon is rather well isolated from its congeners and indeed represents a good species, not just one of weakly differentiated morphotypes that are so numerous in the $C$. album aggregate.

\section{Discussion}

Specimens of the new species were first collected by Sergei Mosyakin in 1989 in Hrebinky (also sometimes transliterated as Grebinky), Vasylkiv District, Kyiv Region, Ukraine (specimens in KW, all collected by S. Mosyakin: 5 August 1989, No. 092184; 18 August 1991, Nos. 008141, 008142, 008143, 008144, etc., plus numerous specimens collected during 2015-2020). The plants were initially discovered in shady places in a small park and adjacent ruderal habitats near the Kyiv-Odesa (Odessa) highway, not far from a grain elevator. It was evident to the first author already in the early 1990s that the newly found Chenopodium represented a species morphologically different from all other species of the genus known in Ukraine. The proximity of the elevator and the main highway suggested that the species was introduced there, and because of that early attempts at its identification were aimed at finding a morphologically best-matching taxon from other parts of the world (see below). Only special observations (morphology, ecology, phenology, etc.) and extensive serial herbarium collections made by Sergei Mosyakin mainly during 2015-2020, combined with data of chromosome counts (initially provided by colleagues from the Institute of Food Biotechnology and Genomics of the National Academy of Sciences of Ukraine, and then in more detail by the research team of Bohumil Mandák) and further karyological and molecular results obtained by Mandák and his team, convinced us that the plants observed and collected in Ukraine represent a distinct new species.

Ukrainian Botanical Journal, 2020, 77(4) 
Initially the plants collected in the first known locality were suspected to represent some morphotypes of Chenopodium missouriense Aellen (C. album var. missouriense (Aellen) Bassett \& Crompton); not the European plants usually identified (or misidentified?) as C. missouriense but some forms of North American plants seen by Sergei Mosyakin in MO, US, and some other North American herbaria (Mosyakin, 1996; see also comments in Clemants, Mosyakin, 2003; Mosyakin, 2012).

It should be noted that the real taxonomic identity of C. missouriense remains at least problematic until now. Confusingly, in the protologue (Aellen, 1928, see also Aellen, 1929, 1960-1961; Aellen, Just, 1943) the specimens of that newly described species were cited from Europe (Sweden, collected by C. Blom), but at the same time it was noted that the original description was based on North American specimens collected by B.F. Bush in the United States (Courtney, Jackson County, Missouri). Dvořák (1987: 580) concluded that original specimens of C. missouriense represent "a mingled material of at least two taxa"; in our opinion, that suggestion is correct. There are two lectotype designations available in literature for the name $C$. missouriense, one made by Bassett and Crompton (1982; US00513035, the image available from http://n2t.net/ark:/65665/3b9ee86dd-02c8-44cc-926f77b8bf3aa110), which should be followed, and another made by Dvořák (1987) on a specimen from G.

As mentioned by Mosyakin (1996), it looks like the common "European" concept of C. missouriense does not match most of North American plants identifiable as that species. Because of that uncertainty Clemants and Mosyakin (2003) in their treatment of Chenopodium in the Flora of North America did not include C. missouriense in the identification key and the list of numbered species but instead discussed it in a note under C. album sensu lato, together with other problematic taxa. It is quite possible that most of the European plants (mainly hexaploids?) identified as C. missouriense (see Aellen, 1928, 1929, 1931; Dvořák, 1987; Dostálek, Jehlík, 2004; Grozeva, 2014, Mered'a et al., 2016, etc.) are in fact neither identical with nor directly related to native North American plants identifiable as that species. Dvořák (1987: 581) stated that the hexaploid chromosome numbers reported for $C$. missouriense in several publications should be critically revised because they most probably refer to various morphotypes of C. album sensu lato; he also hypothesized that the "true" North American $C$. missouriense might be related to $C$. virgatum Thunb. (that name remains unresolved taxonomically; referable to a problematic East Asian taxon) and C. striatiforme Murr (a Eurasian tetraploid). However, his ideas about origins of the European plants identified (or misidentified) as C. missouriense have not been confirmed. Clemants and Mosyakin (2003) noted that some North American plants identifiable as C. missouriense have inflorescences that are somewhat reminiscent of those of the native North American A-genome diploid C. standleyanum Aellen. Further comments on the proper identity and typification of C. missouriense and some other enigmatic or taxonomically unresolved taxa described or recognized by Aellen will be provided in a separate article (now in progress).

Despite superficial similarity of some North American specimens identifiable as $C$. missouriense to our plants described here as C. ucrainicum, they are morphologically quite different and definitely do not belong to the same species. Also, C. missouriense was reported to be a hexaploid with $2 n=54$ (Bassett, Crompton, 1982; Mandák et al., 2018, and references therein), Dvořák (1987) instead suggested relationships of presumably native North American plants with tetraploids (see above), while our new species is diploid.

Another hypothesis explored for establishing the taxonomic identity of Ukrainian plants occasionally collected since 1989 was their possible identification as C. borbasii Murr (= C. album subsp. borbasii (Murr) Soó) (see Dvořák, 1991, and references therein); and that name was tentatively accepted in Conspectus Florae Europae Orientalis (Mosyakin, 2012; earlier also mentioned as a possibility: Mosyakin, 1996: 43). However, comparison of our plants with actual specimens of $C$. borbasii (including syntypes) reliably identified by Aellen and Murr in $\mathrm{G}$ and $\mathrm{W}$ during the visits of the first author (S. Mosyakin) to these herbaria in 2017 and 2018 , respectively, as well as our analysis of the relevant literature and digital images of herbarium specimens available online, leaved no doubt that our plants do not belong to that taxon. Also, C. borbasii is reported to be a hexaploid (Dvořák, 1991; Lomonosova in Marhold, 2013: 1358, E9), in contrast to our diploid plants.

In its leaf shape C. ucrainicum superficially resembles some morphotypes of the South American tetraploid species C. hircinum Schrad. (see Mosyakin, Sokolova, 2020, and references therein) and the East EuropeanSiberian alluvial psammophytic tetraploid $C$. acerifolium Andrz. (see Uotila, Lomonosova, 2016; Mosyakin, 2017, and references therein) (Fig. E14). However, the fruit/ seed morphology, ploidy levels, and genome/subgenome 
composition convincingly demonstrate that neither of these two taxa is conspecific with C. ucrainicum, and they are not even closely related.

Chenopodium ucrainicum should be also compared with $C$. lobodontum H.Scholz, a species described from the city of Berlin, Germany, and hypothesized to be of synanthropic origin, "promoted by hybrid contact of Ch. suecicum, Ch. album and Ch. strictum" (Scholz, 1999; see also Zerbe et al., 2003). It was also reported as a rather late-flowering and fruiting species (SeptemberOctober) with the diploid chromosome number $2 n=18$ (resembling in that respect, and also in morphology, C. suecicum), but the tetraploid number $2 n=36$ was also mentioned. However, judging from its detailed original description, illustrations in the protologue, and the digital images of the holotype (available at https://herbarium. bgbm.org/object/B100277962 and https://plants.jstor. org/stable/10.5555/al.ap.specimen.b_10_0277962) and other specimens at B identified by H. Scholz, morphological characters of that species (such as its leaf shape and dark green or grayish-green leaf color, branching habit, fruit/seed morphology, etc.) do not match those of $C$. ucrainicum, and the distinctions are sufficient enough for treating these two as different taxa. In our opinion, $C$. lobodontum is either very close to or conspecific with $C$. suecicum, and the hypothesis of its origin by hybridization involving the three species mentioned by Scholz (1999) is unlikely.

We also compared our plants morphologically with available herbarium original and other reliably identified specimens (especially those identified by Murr and/or Aellen in $\mathrm{G}$ and $\mathrm{W}$ ) and with both published and available online images of taxa usually considered to be synonyms, infraspecific entities or close relatives of $C$. suecicum or C. album (Aellen, 1960-1961; Beaugé, 1974; Uotila, Suominen, 1976; Uotila, 1978, 2001; Walter, 1995; Sukhorukov, Zhang, 2013; Sukhorukov, 2014; POWO, 2020-onward, etc.) or sometimes recognized as separate species (e.g., Murr, 1902, 1903, 1904; Dvořák, 1987, 1990, 1991, 1992, etc.), such as C. bernburgense Murr, C. betulifolium Murr, C. haywardiae Murr, C. neumanii Murr, C. pseudopulifolium (Scholz) Murr, C. subopulifolium Murr, and some other morphotypes having species-rank names. To the best of our knowledge, none of the mentioned taxa matched morphologically the species described here as C. ucrainicum.

\section{Concluding remarks}

Chenopodium ucrainicum can be expected to occur not only in Ukraine but also in adjacent and more distant regions of Europe and Asia, where it has not been yet revealed and reported because of its superficial morphological similarity to other taxa (species and infraspecific entities) of the C. album aggregate. We hope that the morphological description and other information, and especially images on the new species provided here, will draw attention of researchers to that taxon. We would greatly appreciate any information from researchers concerning C. ucrainicum, especially reports of its occurrence outside the presently known areas.

Additional information on the new species, including further taxonomic and nomenclatural considerations, results of molecular, karyological, micromorphological and other studies, etc., will be published in the forthcoming article, which is now in preparation.

\section{Acknowledgments}

We are grateful to Svitlana I. Antonenko (KW - M.G. Kholodny Institute of Botany, National Academy of Sciences of Ukraine, Kyiv, Ukraine) for digitizing the herbarium specimens, to Tetiana S. Dvirna and Dmytro O. Klymchuk (KW) for their assistance with photomicrographs, and to Nataila $\mathrm{M}$. Shiyan (Head Curator, KW), Alisa V. Shumilova and Iryna I. Diachenko (Curatorial Assistants, KW) for providing their assistance at the KW herbarium. Sergei Mosyakin is grateful to curators and staff of many herbaria, especially $\mathrm{G}, \mathrm{K}, \mathrm{MO}$, US, W, for facilitating his work with their collections during research visits. Sergei Mosyakin is also grateful to Yaroslav B. Blume and his team members from the Institute of Food Biotechnology and Genomics of the National Academy of Sciences of Ukraine (Kyiv, Ukraine) for providing early data on the diploid chromosome number of C. ucrainicum. We express our gratitude to members of the research team of Bohumil Mandák for providing their research results that confirmed the species status of $C$. ucrainicum and thus supported its present validation. The generous support of The Andrew W. Mellon Foundation provided in 2007-2016 for digitization of type specimens and capacity building at $\mathrm{KW}$ is greatly appreciated. The taxonomic and nomenclatural work of Sergei Mosyakin was in part supported by the National Academy of Sciences of Ukraine during many years (in particular, project 0117U004024); research of Bohumil Mandák was supported by the Ministry of Education, Youth and Sports of the Czech Republic (LTAUSA18004), the Czech Science Foundation (2020286S), and is part of the long-term research development project RVO 67985939. Finally, we are extremely grateful to reviewers for their useful comments.

Ukrainian Botanical Journal, 2020, 77(4) 


\section{References}

Aellen P. 1928. Neue adventiv Chenopodium aus Schweden. Botaniska Notiser (Lund) [vol. of 1928]: 203-210.

Aellen P. 1929. Beitrag zur Systematik der ChenopodiumArten Amerikas, vorwiegend auf Grund der Sammlung des United States National Museum in Washington, D.C. II [Part 2]. Repertorium Specierum Novarum Regni Vegetabilis 26(7-15): 119-160. https://doi.org/10.1002/ fedr.19290260703

Aellen P. 1931. Die wolladventiven Chenopodien Europas. Verhandlungen der Naturforschenden Gesellschaft in Basel, 41: 77-104.

Aellen P. 1960-1961. Chenopodiaceae. In: Hegi G. Illustrierte Flora von Mitteleuropa, Aufl. 2 ( $2^{\text {nd }}$ ed.), Bd. (vol.) 3, T. (part) 2, Lief. 2-4. München: Lehmann Verlag [Reprinted in 1979: Berlin; Hamburg: Paul Parey Verlag], pp. 533-762.

Aellen P., Just T. 1943. Key and synopsis of the American species of the genus Chenopodium L. American Midland Naturalist, 30(1): 47-76. https://doi.org/10.2307/2421263

Bassett I.J., Crompton C.W. 1982. The genus Chenopodium in Canada. Canadian Journal of Botany, 60(5): 586-610. https://doi.org/10.1139/b82-080

Beaugé A. 1974. Chenopodium album et espèces affines. Étude historique et statistique. Paris: Société d'Edition d'Enseignement Supérieur (SEDES), xx + 447 pp.

Clemants S.E., Mosyakin S.L. 2003. Chenopodium. In: Flora of North America Editorial Committee (eds.). Flora of North America North of Mexico, vol. 4. New York; Oxford: Oxford University Press, pp. 275-299.

Dostálek J., Jehlík V. 2004. Chenopodium probstii and C. missouriense: two North American plant species in the Czech Republic, Slovak Republic and neighbouring countries. Feddes Repertorium, 115(5-6): 483-503. https://doi.org/10.1002/fedr.200411048

Dvořák F. 1987. Study of Chenopodium acerifolium Andrz. and Ch. missouriense Aellen. Feddes Repertorium, 98(1112): 561-582. https://doi.org/10.1002/fedr.19870981105

Dvořák F. 1990. Study of Chenopodium interjectum J. Murr, Ch. mixtifolium J. Murr and Ch. laciniatum J. Murr. Feddes Repertorium, 101(7-8): 347-371. https://doi.org/10.1002/ fedr.19901010706

Dvořák F. 1991. Study on Chenopodium borbasii J. Murr. Feddes Repertorium, 102(5-6): 351-373. https://doi. org/10.1002/fedr.19911020506

Dvořák F. 1992. Study on Chenopodium subopulifolium J. Murr emend D. Feddes Repertorium, 103(1-2): 49-69. https://doi.org/10.1002/fedr.19921030109

Fuentes-Bazan S., Uotila P., Borsch T. 2012. A novel phylogeny-based generic classification for Chenopodium sensu lato, and a tribal rearrangement of Chenopodioideae (Chenopodiaceae). Willdenowia 42: 5-24. https://doi. org/10.3372/wi.42.42101

Grozeva N. 2014. A comparative morphological characteristics of Chenopodium album L., C. missouriense Aellen and C. probstii Aellen. Turkish Journal of Agricultural and
Natural Sciences, 2 (Special Issue): 1949-1954. Available at: https://dergipark.org.tr/tr/download/article-file/142366

JSTOR Global Plants. 2020-onward. Available at: https:// plants.jstor.org (Accessed constantly during the preparation of the manuscript, last accessed during the final revision 25 August 2020).

Krak K., Vít P., Belyayev A., Douda J., Hreusová L., Mandák B. 2016. Allopolyploid origin of Chenopodium album s. str. (Chenopodiaceae): A molecular and cytogenetic insight. PLoS ONE, 11(8): e0161063. https://doi.org/10.1371/ journal.pone.0161063

Mandák B., Trávníček P., Paštová L., Kořínková D. 2012. Is hybridization involved in the evolution of the Chenopodium album aggregate? An analysis based on chromosome counts and genome size estimation. Flora, 207: 530-540. https://doi.org/10.1016/j.flora.2012.03.010

Mandák B., Krak K., Vít P., Lomonosova M.N., Belyayev A., Habibi F., Wang L., Douda J., Štorchová H. 2018. Hybridization and polyploidization within the Chenopodium album aggregate analysed by means of cytological and molecular markers. Molecular Phylogenetics and Evolution, 129: 189-201. https://doi. org/10.1016/j.ympev.2018.08.016

Marhold K. (ed.) 2013. IAPT/IOPB chromosome data 16. Taxon, 62(6): 1356-1361, E1-E16. http://dx.doi. org/10.12705/626.41

Mered'a P. jun., Schwarzová T., Zaliberová M. 2016. Chenopodium. In: Goliašová K., Michalková E. (eds.). Flóra Slovenska, vol. 6(4). Bratislava: VEDA, vydavatel'stvo Slovenskej akadémie vied, pp. 265-305.

Mosyakin S.L. 1996. Chenopodium. In: Tzvelev N.N. (ed.). Flora Europae Orientalis, vol. 9. St. Petersburg: Mir i Sem'ya-95, pp. 27-44. [Мосякин С.Л. 1996. Chenopodium. В кн.: Флора Восточной Eвропь, т. 9. Ред. Н.Н. Цвелев. Санкт-Петербург: Мир и Семья-95, c. 27-44].

Mosyakin S.L. 2012. Chenopodium. In: Tzvelev N.N., Geltman D.V. (eds.). Conspectus Florae Europae Orientalis, vol. 1. KMK Scientific Press, St. Petersburg; Moscow, pp. 280-286. [Мосякин С.Л. 2012. Chenopodium. В кн.: Конспект флоры Восточной Eвponbl, т. 1. Ред. Н.Н. Цвелев, Д.В. Гельтман. СанктПетербург; Москва: Товарищество научных изданий KMK, c. 280-286].

Mosyakin S.L. 2017. Notes on taxonomy and nomenclature of Chenopodium acerifolium and C. betaceum (C. strictum auct.) (Chenopodiaceae). Phytotaxa, 324(2): 139-154. https://doi.org/10.11646/phytotaxa.324.2.3

Mosyakin S.L., Sokolova I.V. 2020. Lectotypification of the name Chenopodium hircinum, a wild relative of the pseudocereal crop species C. quinoa (Chenopodiaceae). Phytotaxa, 432: 190-198. https://doi.org/10.11646/ phytotaxa.432.2.8

Murr J. 1902. Chenopodium-Beiträge. Magyar Botanikai Lapok, 1: 337-344; 359-369.

Murr J. 1903. Chenopodium-Beiträge (Continuatio et finis). Magyar Botanikai Lapok, 2: 4-11. 
Murr J. 1904. Versuch einer natürlichen Gliederung der mitteleuropäischen Formen des Chenopodium album L. In: Urban I., Graebner P. (eds.). Festschrift zur Feier des siebzigsten Geburtstages des Herrn Professor Dr. Paul Ascherson (4. Juni 1904) verfasst von Freunden und Schülern. Leipzig: Verlag von Gebrüder Borntraeger, pp. 216-230.

POWO. 2020-onward. Plants of the World Online. Facilitated by the Royal Botanic Gardens, Kew. Available at: http:// www.plantsoftheworldonline.org (Accessed 18 July 2020).

Scholz H. 1999. 50 Jahre Chenopodium lobodontum spec. nova in Berlin. Verhandlungen des Botanischen Vereins von Berlin und Brandenburg, 132: 5-17.

Sukhorukov A.P. 2014. The carpology of the family Chenopodiaceae in relations to problems of phylogeny, systematics and diagnostics of its representatives. Tula: Grif i K, 400 pp. [Сухоруков А.П. 2014. Карпология семейства Chenopodiaceae в связи с проблемами филогении, систематики и диагностики его представителей. Тула: Гриф и К., 400 с.]

Sukhorukov A.P., Zhang M. 2013. Fruit and seed anatomy of Chenopodium and related genera (Chenopodioideae, Chenopodiaceae/Amaranthaceae): Implications for evolution and taxonomy. PLoS ONE, 8(4): e61906 (18 pp.) https://doi.org/10.1371/journal.pone.0061906

Thiers B. 2008-onward. Index Herbariorum. A global directory of public herbaria and associated staff. New York Botanical Garden's Virtual Herbarium. Available at: http://sweetgum.nybg.org/science/ih (Accessed 18 July 2020).

Turland N.J., Wiersema J.H., Barrie F.R., Greuter W., Hawksworth D.L., Herendeen P.S., Knapp S., Kusber W.-H., Li D.-Z., Marhold K., May T.W., McNeill J., Monro A.M., Prado J., Price M.J., Smith G.F. 2018. International Code of Nomenclature for algae, fungi, and plants (Shenzhen Code) adopted by the Nineteenth International Botanical Congress, Shenzhen, China, July 2017 [Regnum Vegetabile, vol. 159]. Glashütten: Koeltz Botanical Books, xxxviii + 254 pp. https://doi. org/10.12705/Code.2018

Uotila P. 1978. Variation, distribution and taxonomy of Chenopodium suecicum and C. album in N. Europe. Acta Botanica Fennica 108: 1-35.

Uotila P. 2001. Chenopodium. In: Jonsell B. (ed.). Flora Nordica, vol. 2. Stockholm: Bergius Foundation, Royal Swedish Academy of Sciences, pp. 4-31.

Uotila P., Lomonosova M.N. 2016. Taxonomic circumscription and synonymy of Chenopodium karoi and C. acerifolium (Chenopodiaceae). Annales Botanici Fennici, 53(3-4): 223-237. https://doi.org/10.5735/085.053.0411

Uotila P., Suominen J. 1976. The Chenopodium species in Finland, their occurrence and means of immigration. Annales Botanici Fennici 13(1): 1-25.

Walsh B.M., Adhikary D., Maughan P.J., Emshwiller E., Jellen E.N. 2015. Chenopodium polyploidy inferences from Salt Overly Sensitive 1 (SOS1) data. American Journal of Botany, 102(4): 533-543. https://doi. org/10.3732/ajb.1400344

Walter J. 1995. Zwei bisher in Österreich wenig bekannte Chenopodien: Ch. suecicum und Ch. album subsp. pedunculare. Florae Austriae Novitates, 2: 28-53. Available at: https://www.zobodat.at/pdf/Fl-AustrNovit_2_0028-0053.pdf

Zerbe S., Maurer U., Schmitz S., Sukopp H. 2003. Biodiversity in Berlin and its potential for nature conservation. Landscape and Urban Planning, 62: 139-148. https://doi. org/10.1016/S0169-2046(02)00145-7

Recommended for publication by M.M. Fedoronchuk 
Electronic Supplement to: Mosyakin \& Mandák. 2020. Chenopodium ucrainicum (Chenopodiaceae / Amaranthaceae sensu APG), a new diploid species: a morphological description and pictorial guide. Ukrainian Botanical Journal, 77(4)

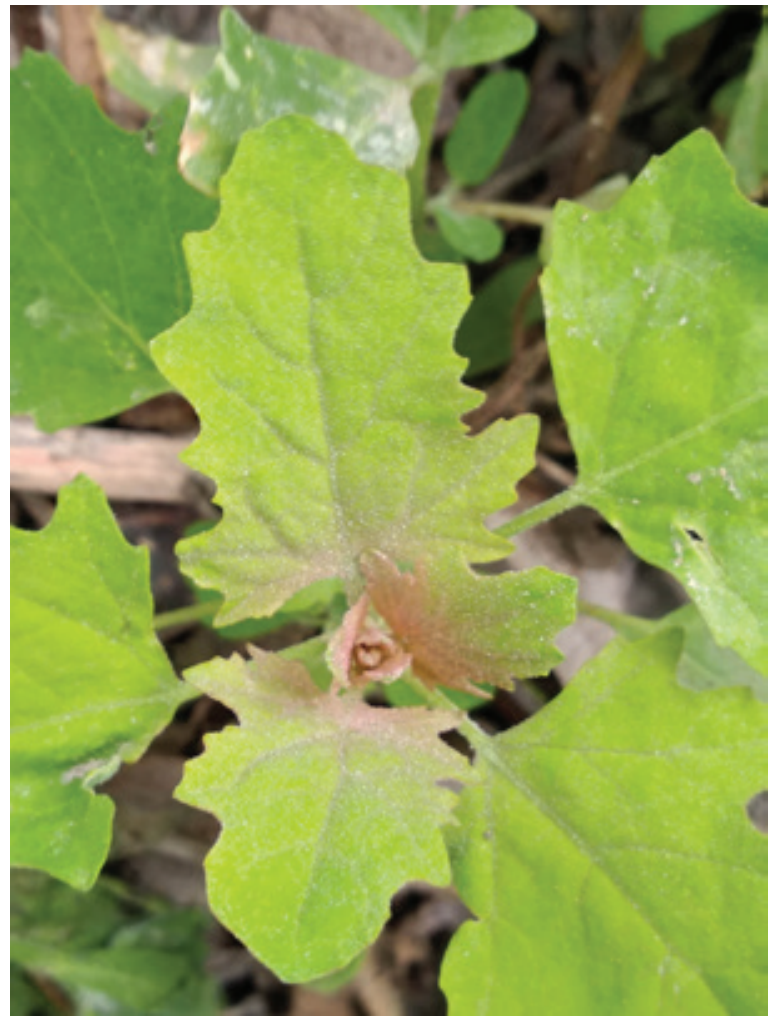

Fig. E1. Young upper leaves of Chenopodium ucrainicum with golden-pinkish mealy indumentum. Kyiv Region, Hrebinky, 16 May 2020

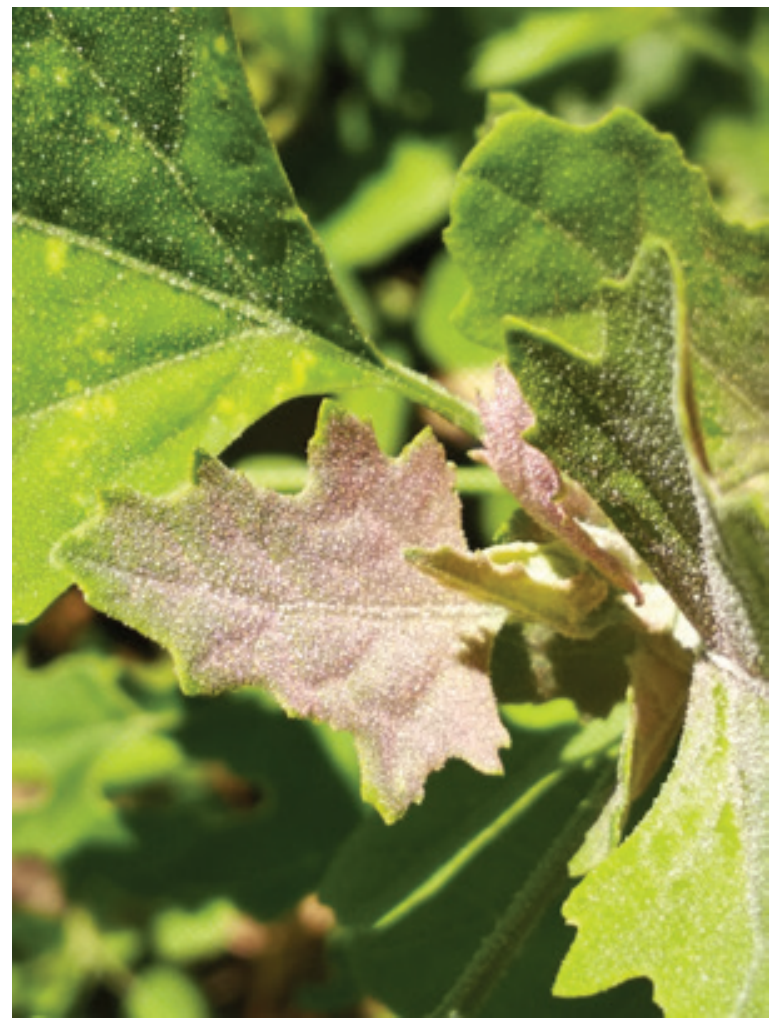

Fig. E2. Young upper leaves of Chenopodium ucrainicum with golden-pinkish mealy indumentum. Kyiv Region, Hrebinky, 6 July 2019

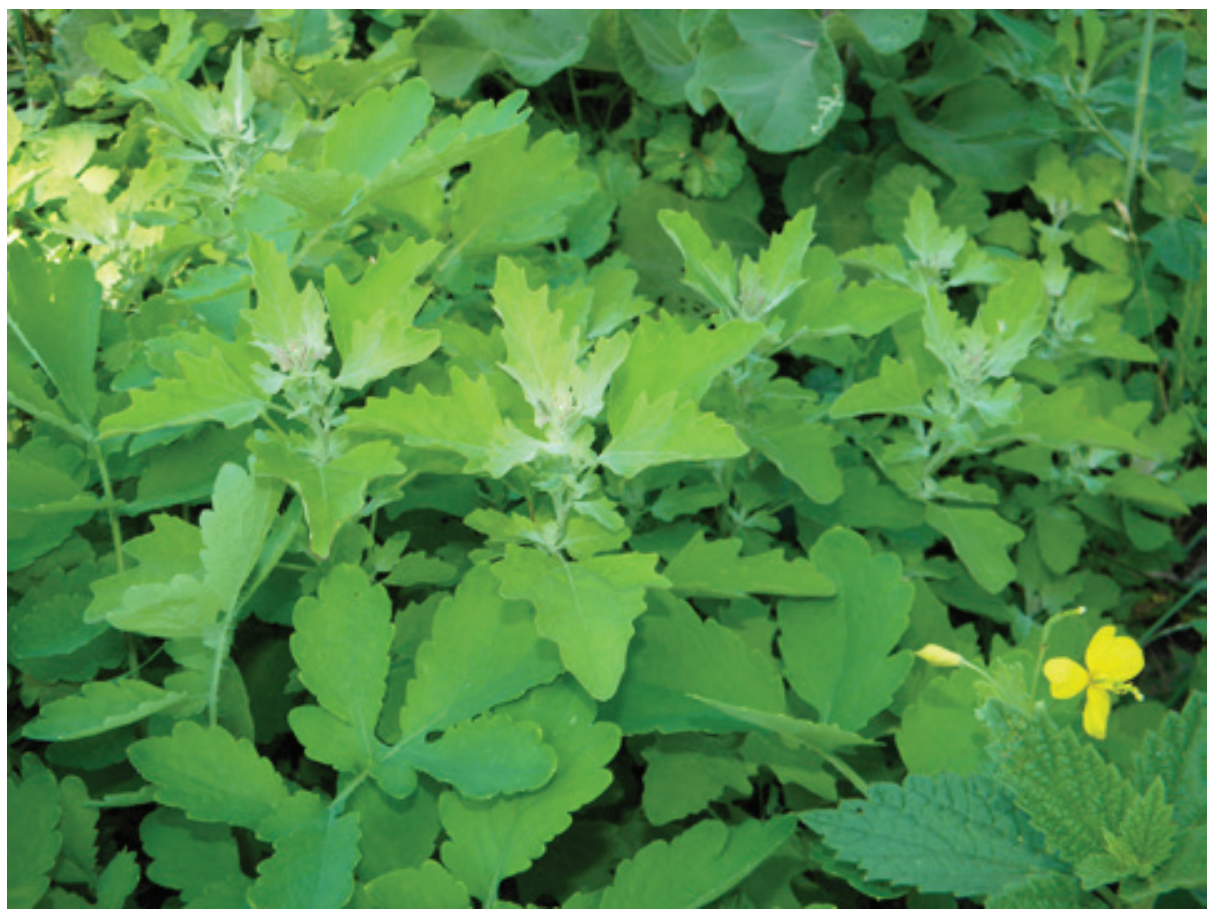

Fig. E3. Young plants of Chenopodium ucrainicum. Kyiv city, locus classicus, 7 July 2018 


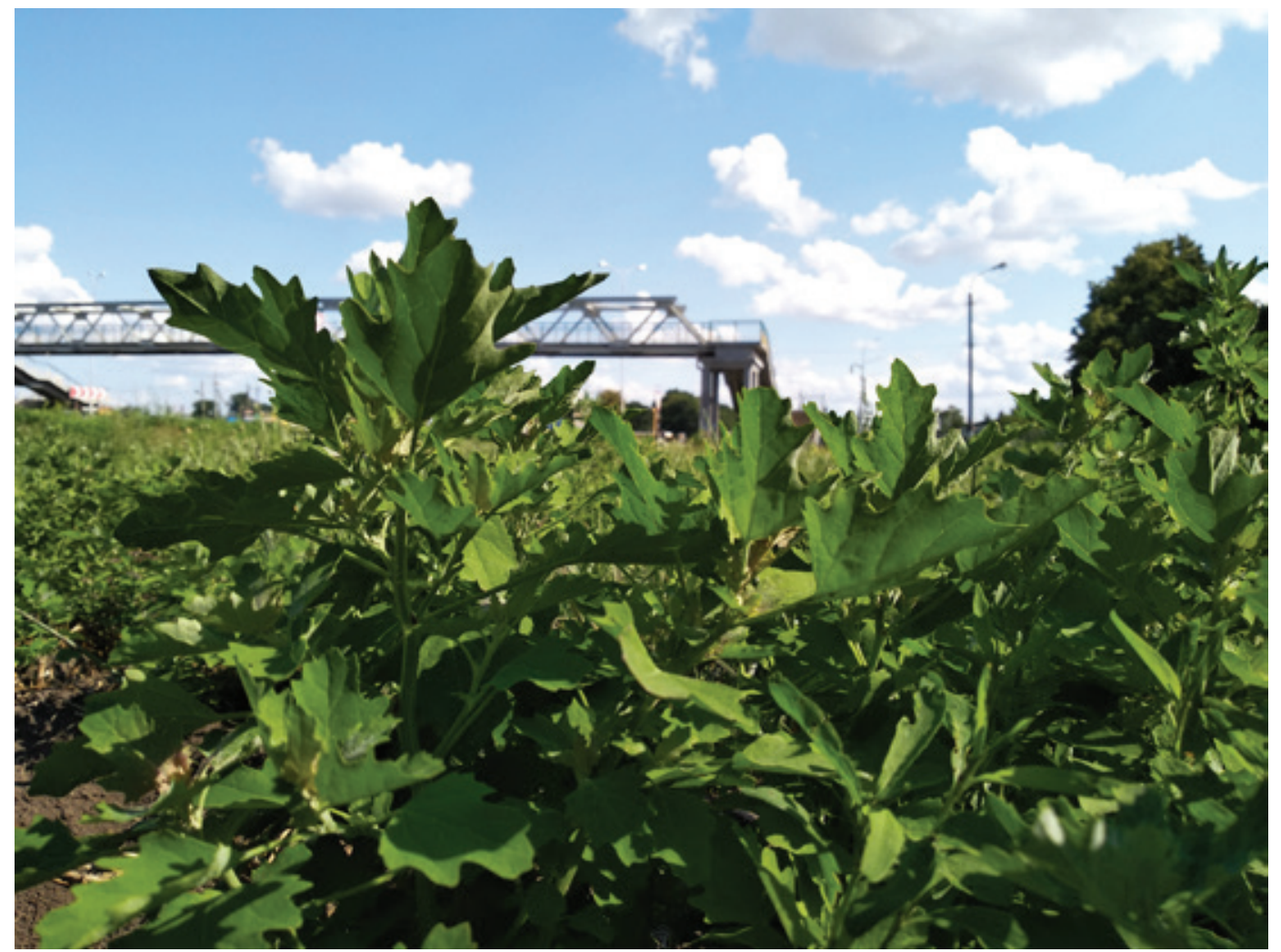

Fig. E4. Plants of Chenopodium ucrainicum growing along the Kyiv-Odesa highway. Kyiv Region, Hrebinky, 13 July 2019

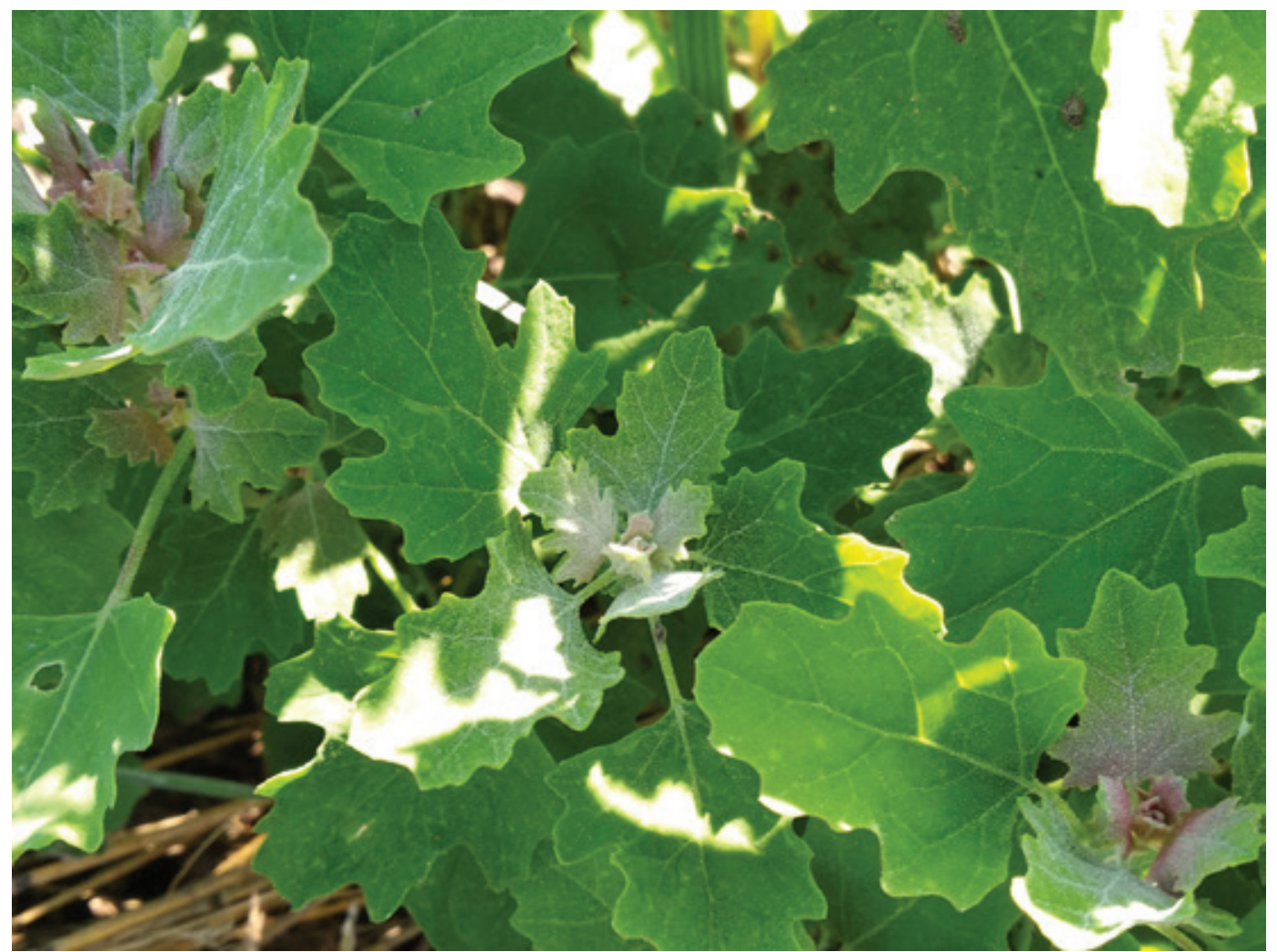

Fig. E5. Plants of Chenopodium ucrainicum. Kyiv Region, Hrebinky, 13 July 2019 


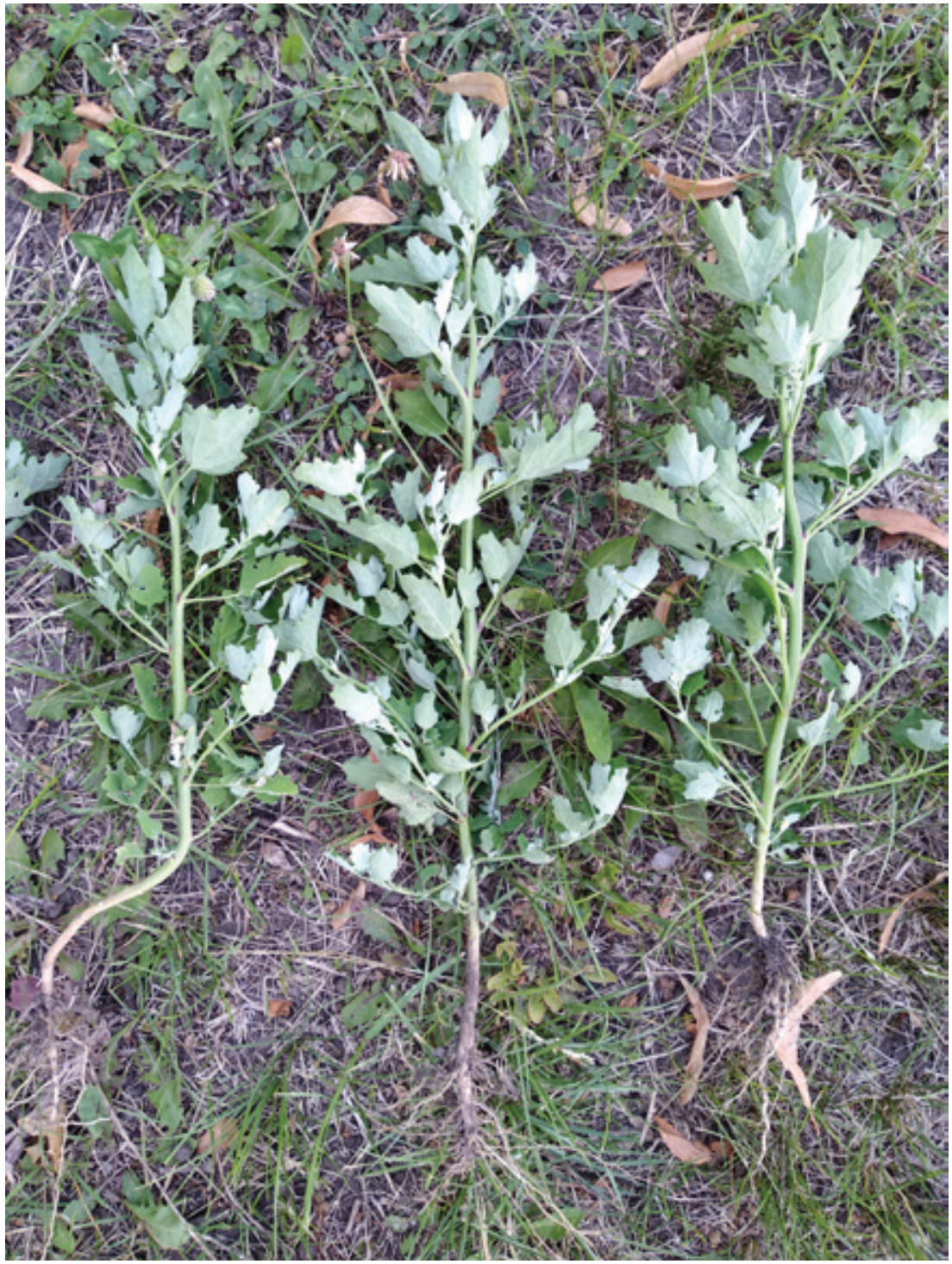

Fig. E6. Plants of Chenopodium ucrainicum collected for the KW herbarium. Kyiv Region, Hrebinky, 13 July 2019

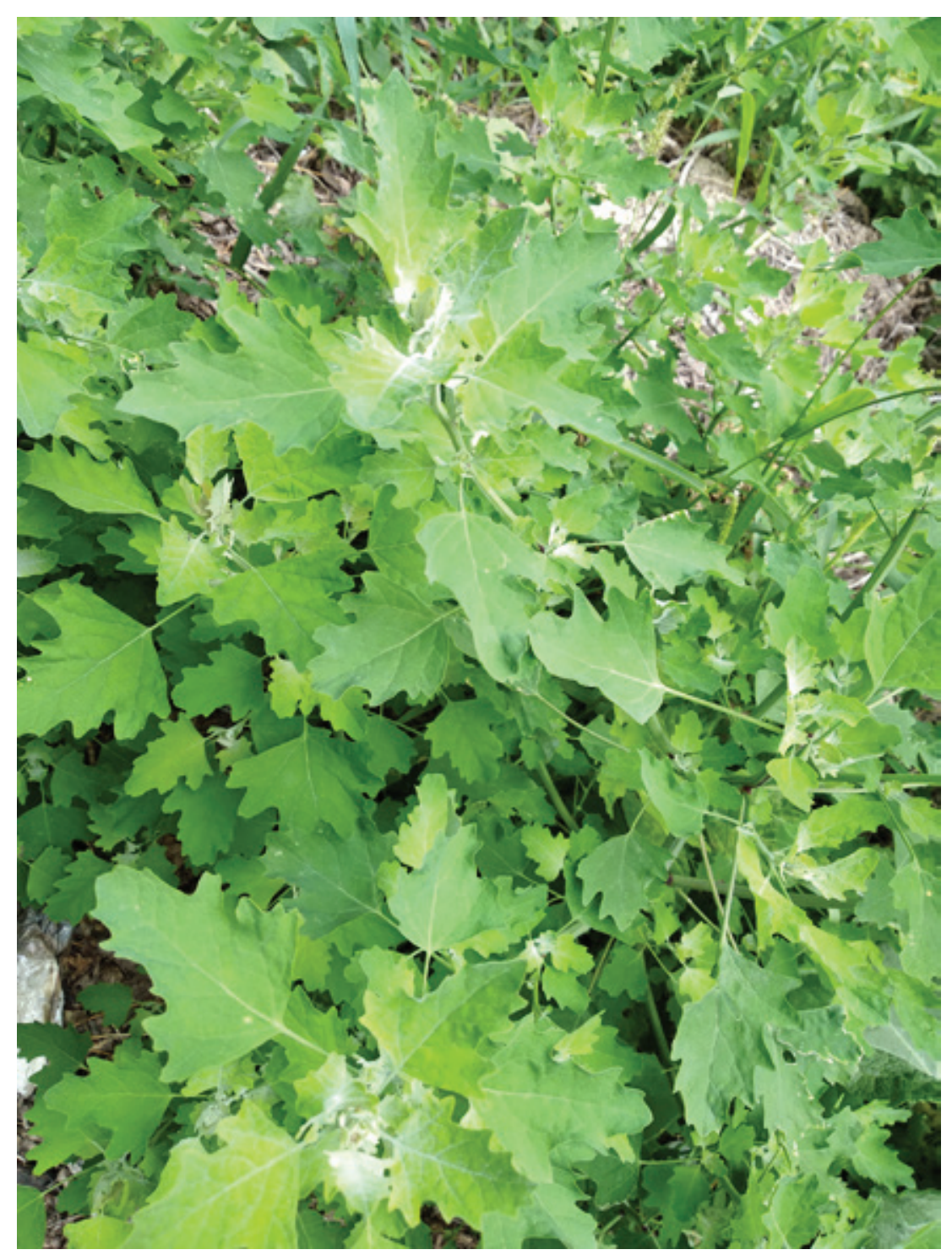

Fig. E7. Plants of Chenopodium ucrainicum. Kyiv city, locus classicus, 17 July 2019 e3 


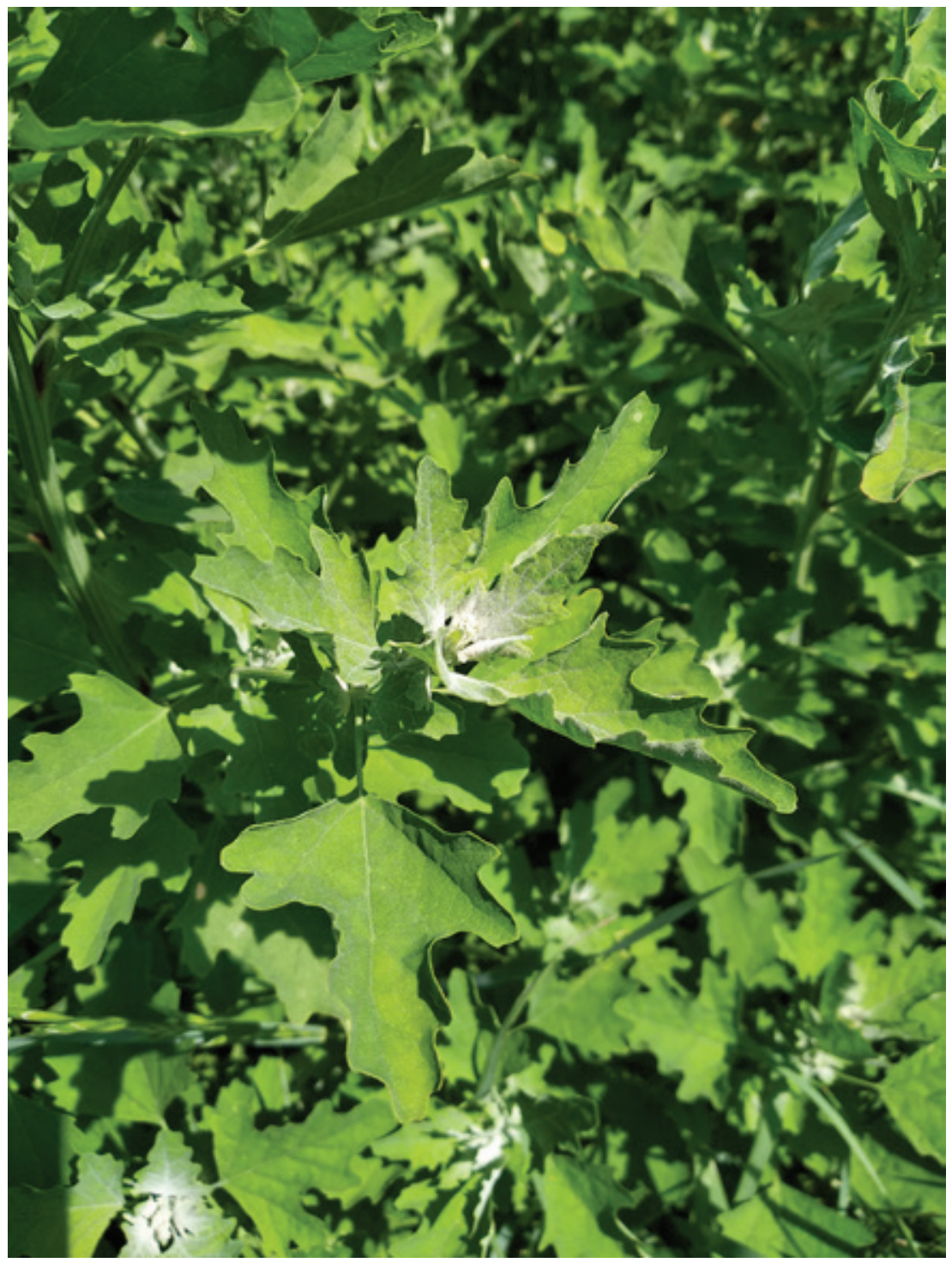

Fig. E8. Chenopodium ucrainicum. Kyiv Region, Hrebinky, 20 July 2019

e4

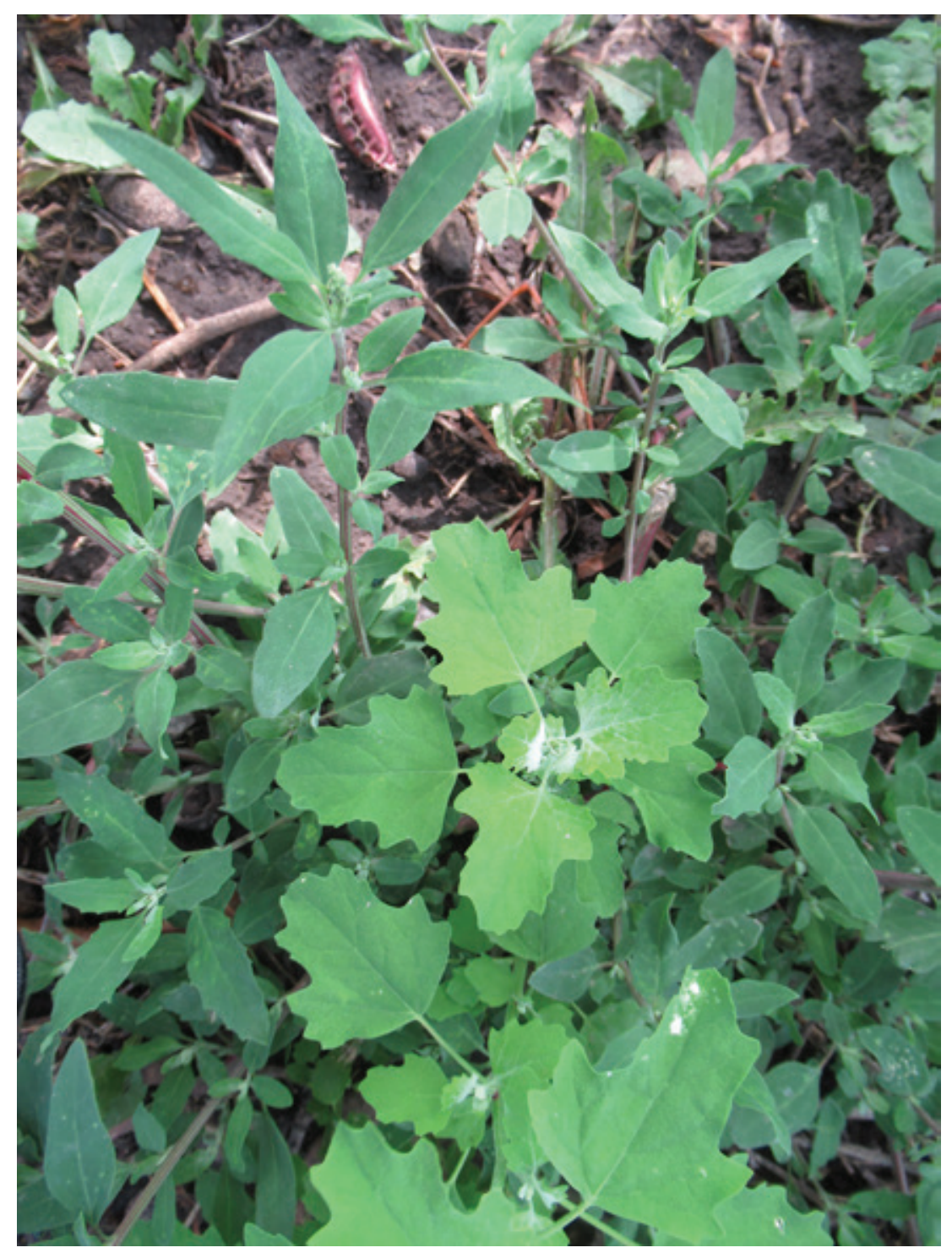

Fig. E9. Chenopodium ucrainicum growing together with C. betaceum. Chenopodium album and C. ficifolium were also present at this site. Kyiv Region, Hrebinky, 26 July 2020 


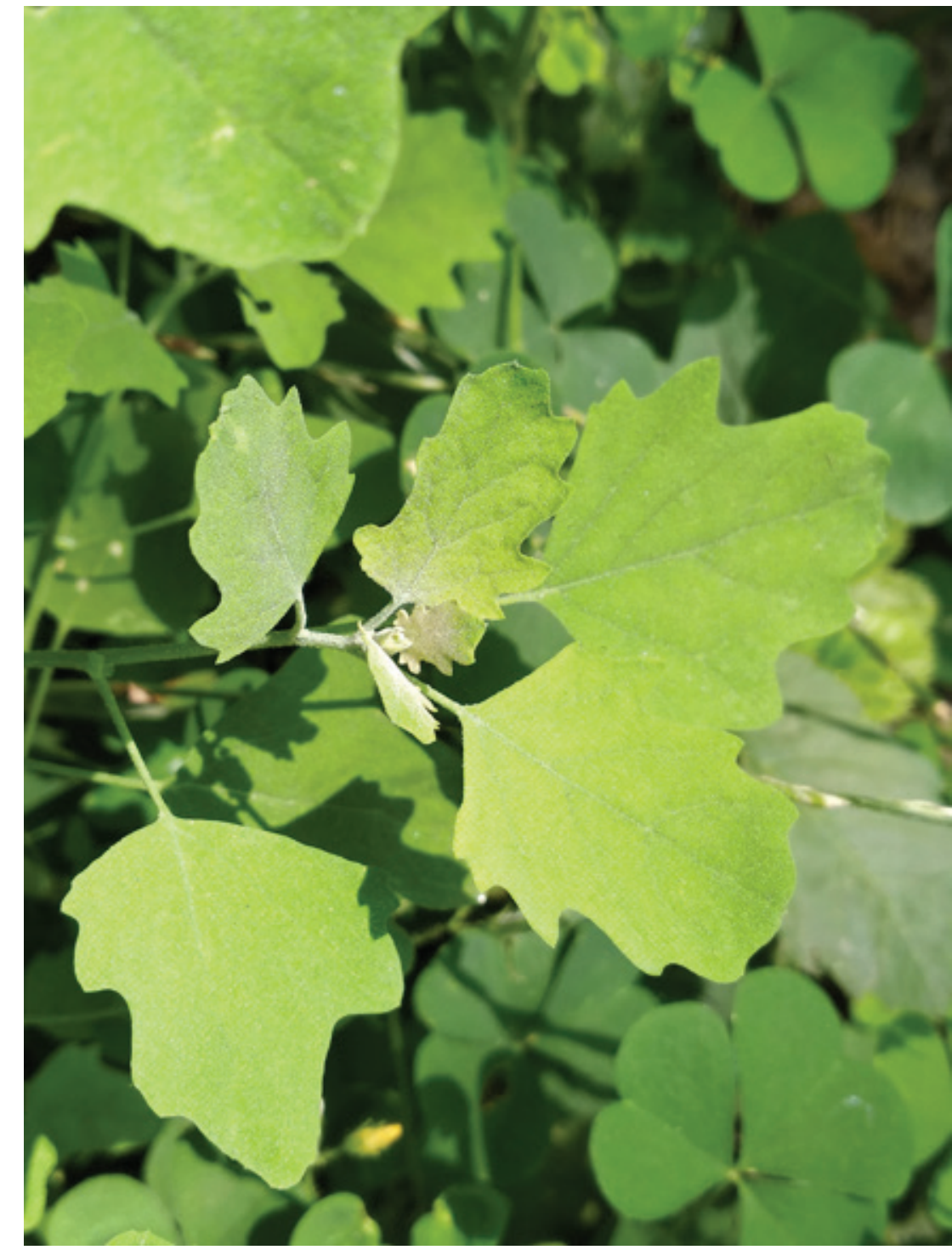

Fig. E10. Chenopodium ucrainicum growing under trees along the Syrets Rivulet. Nyvky Park, W part of Kyiv city, 5 August 2020 e5

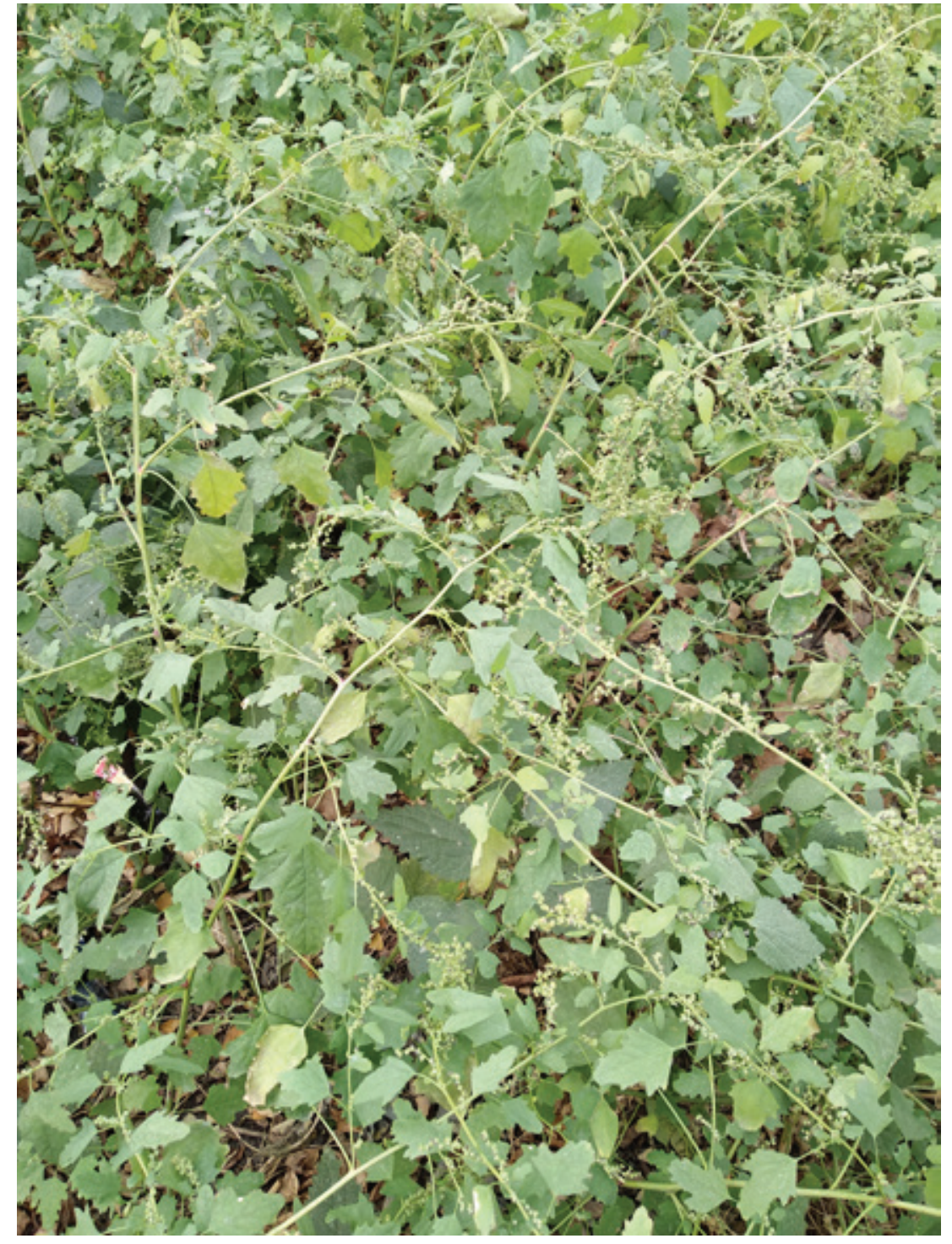

Fig. E11. Chenopodium ucrainicum; fully developed plants in fruit. Kyiv city, locus classicus, 1 November 2019 


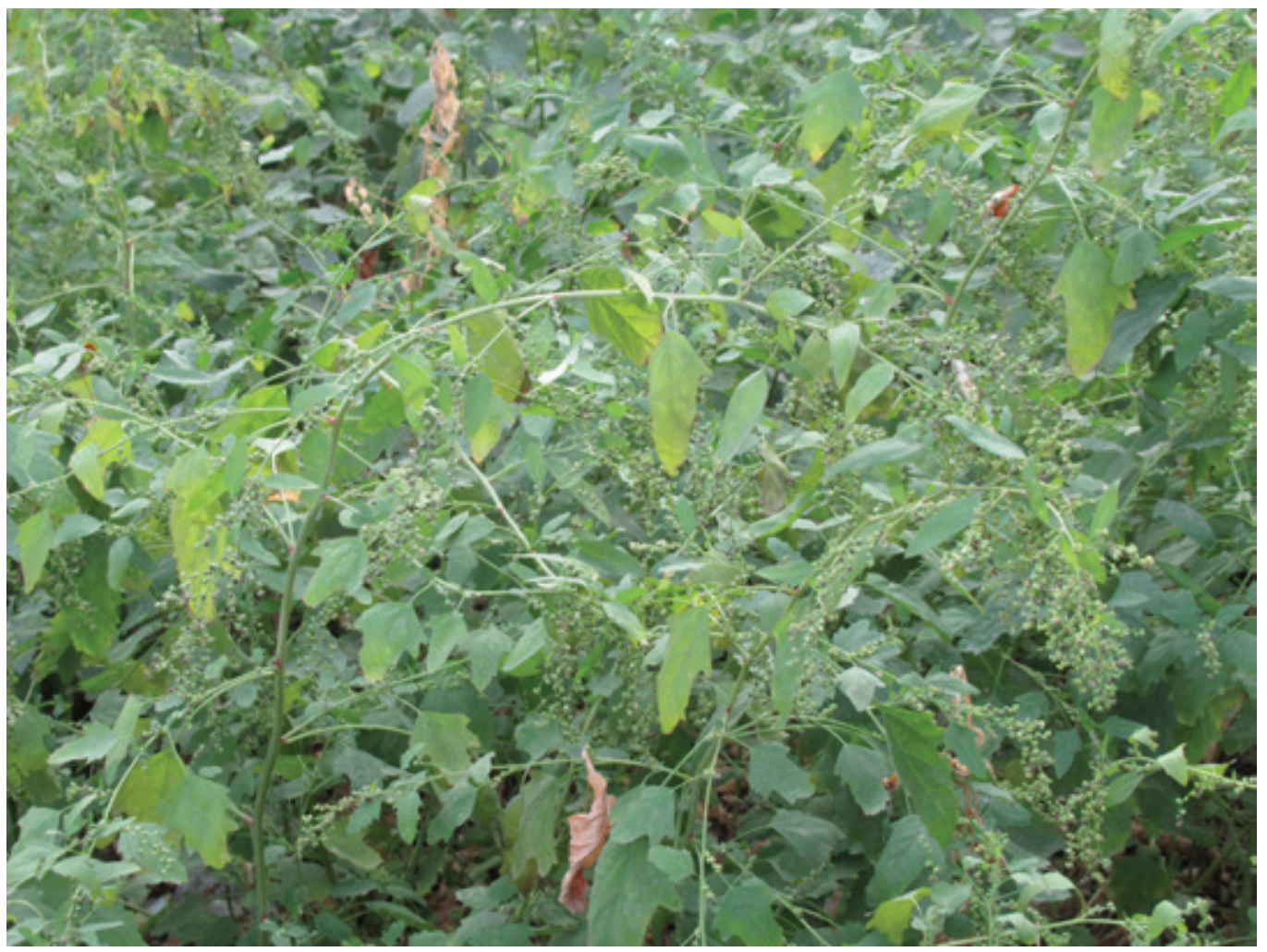

Fig. E12. Chenopodium ucrainicum; fully developed plants in fruit. Kyiv city, locus classicus, 1 November 2019

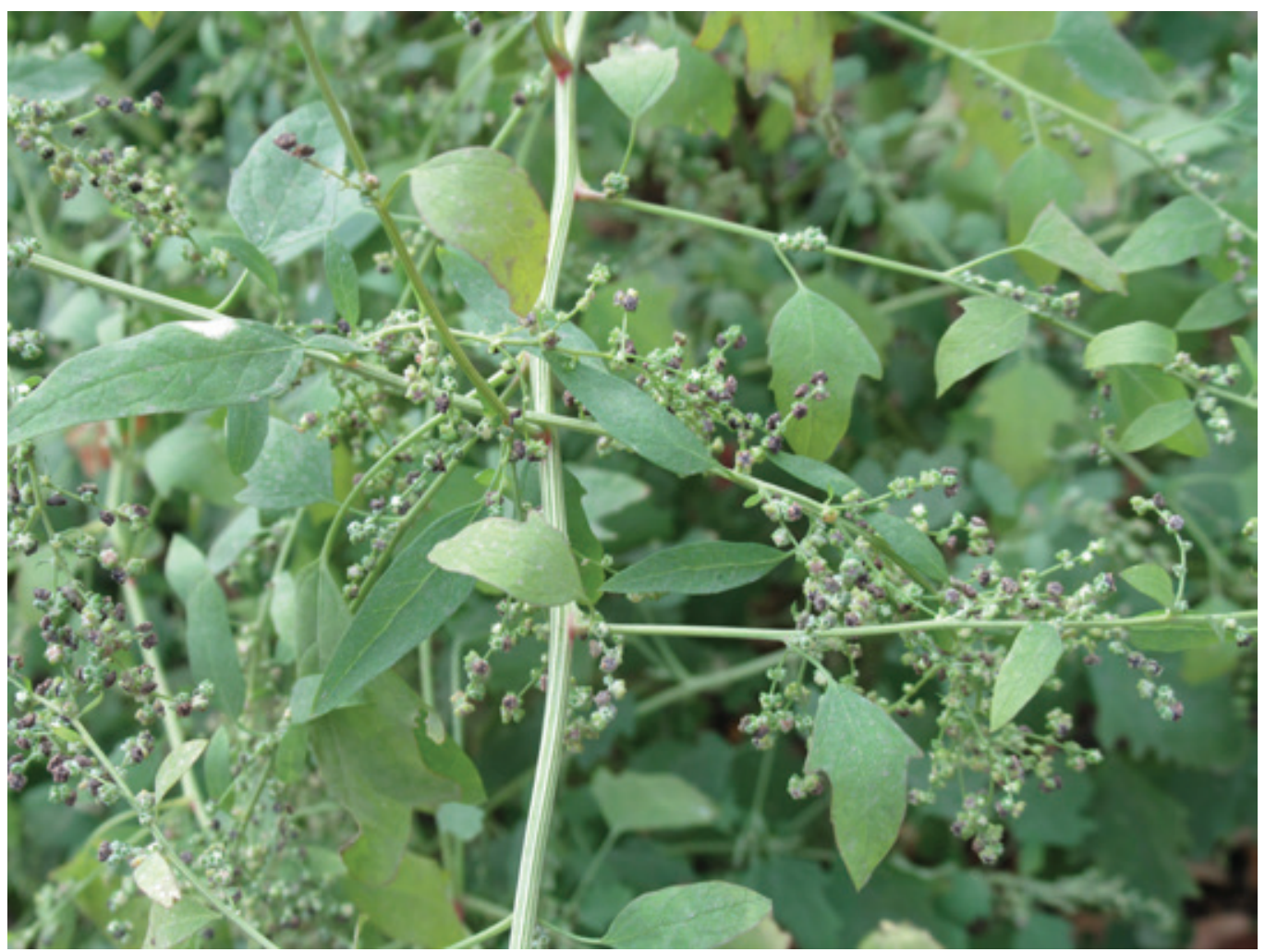

Fig. E13. Chenopodium ucrainicum; a lateral branch of a fully developed plant in fruit, close-up. Kyiv city, locus classicus, 1 November 2019 


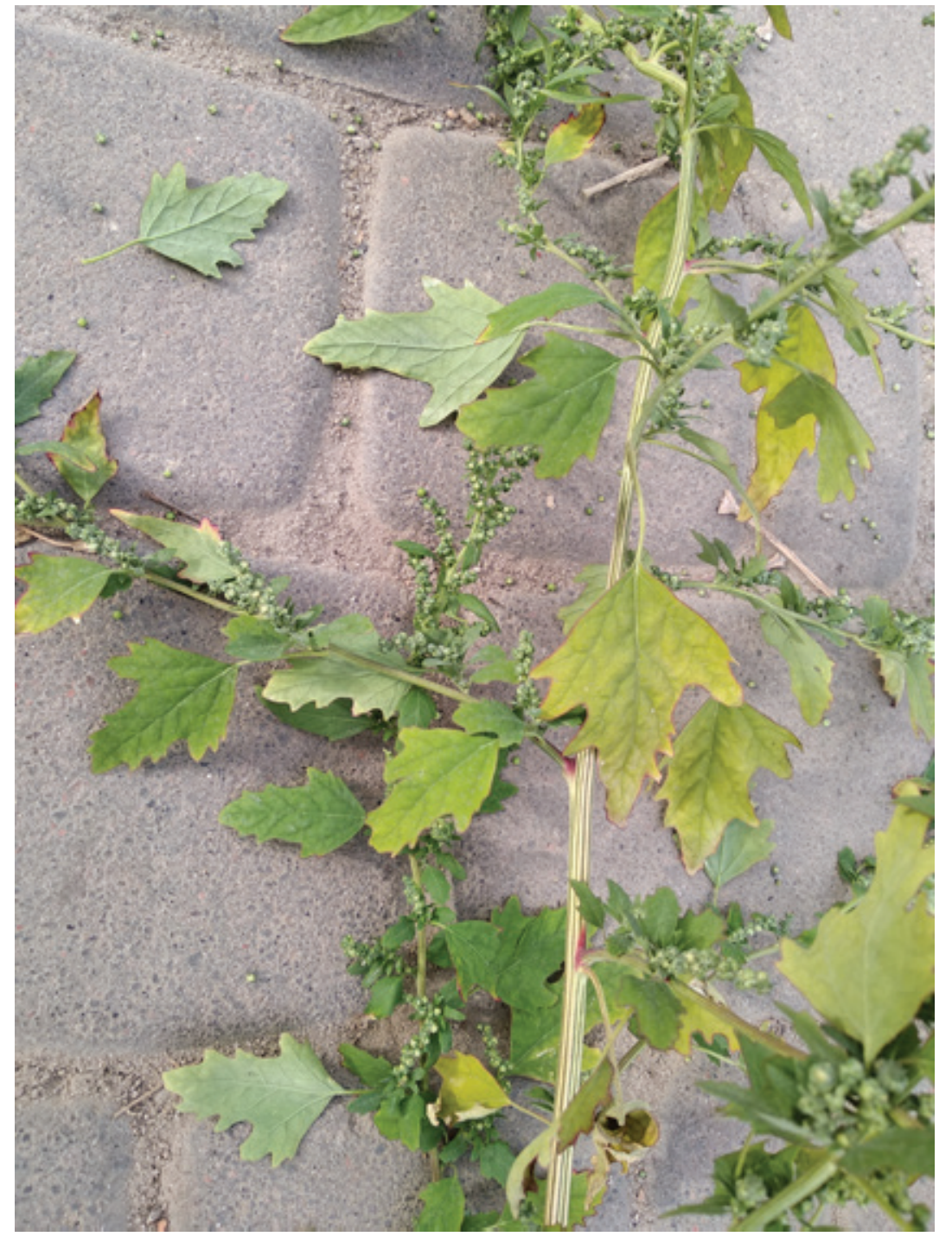

Fig. E14. Chenopodium ucrainicum; a fully developed plant that was growing at an open spot. Kyiv city, locus classicus, 1 November 2019. Note that some leaves are superficially similar to leaves of $C$. acerifolium

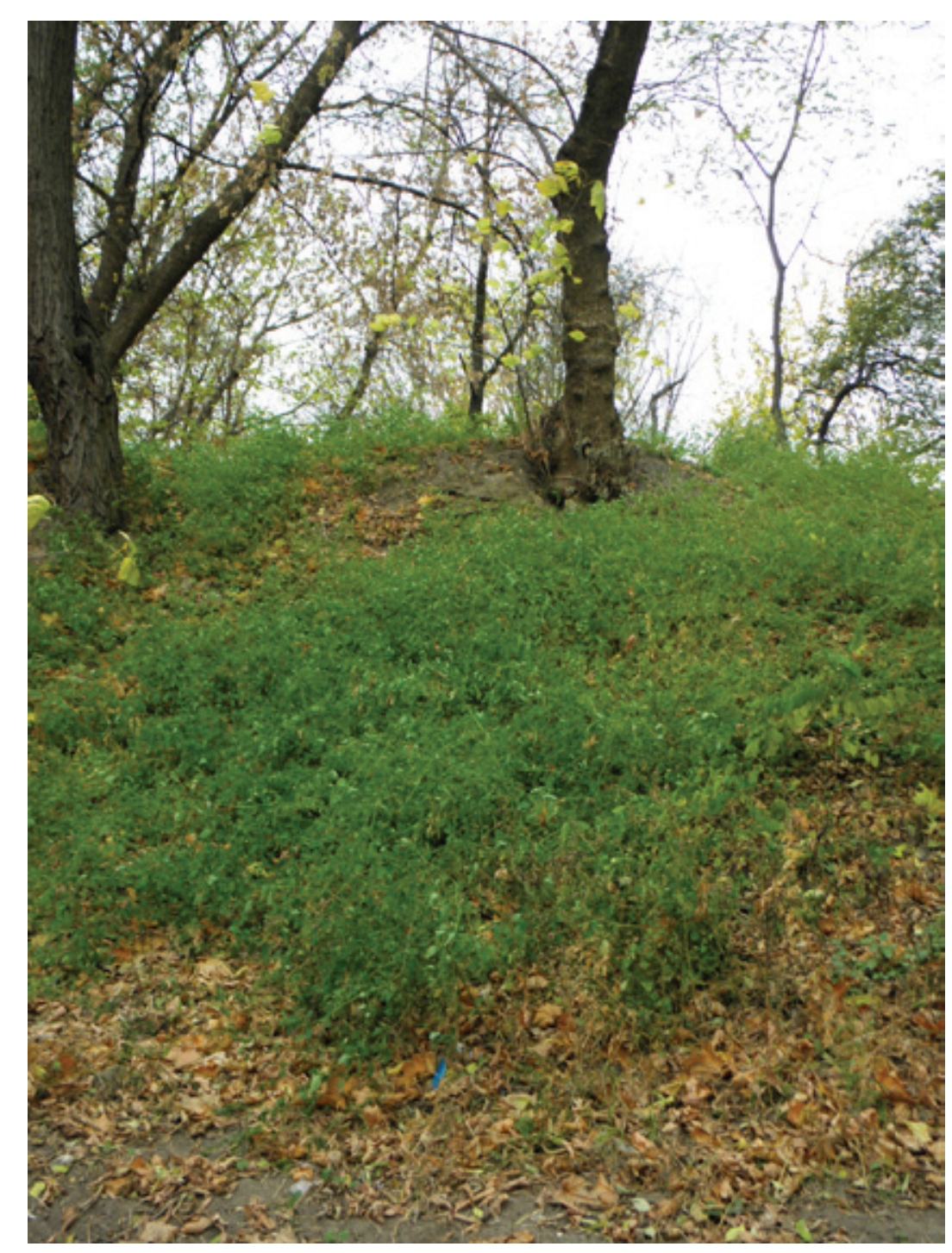

Fig. E15. Groups of plants of Chenopodium ucrainicum, still green in the beginning of November. Kyiv city, locus classicus, 2 November 2018 


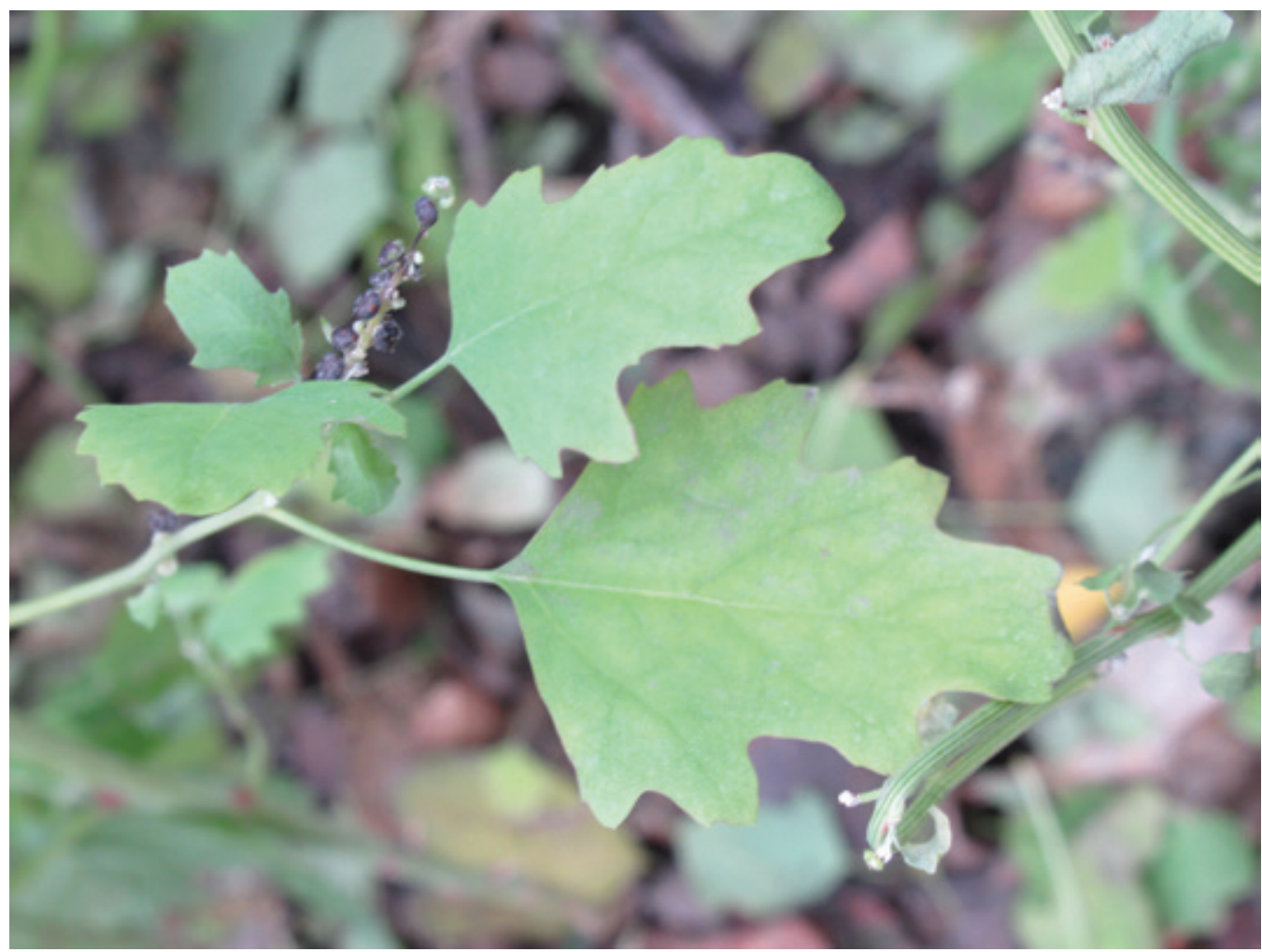

Fig. E16. A lateral branch of Chenopodium ucrainicum with fruits and still green leaves. Kyiv city, locus classicus, 13 November 2019

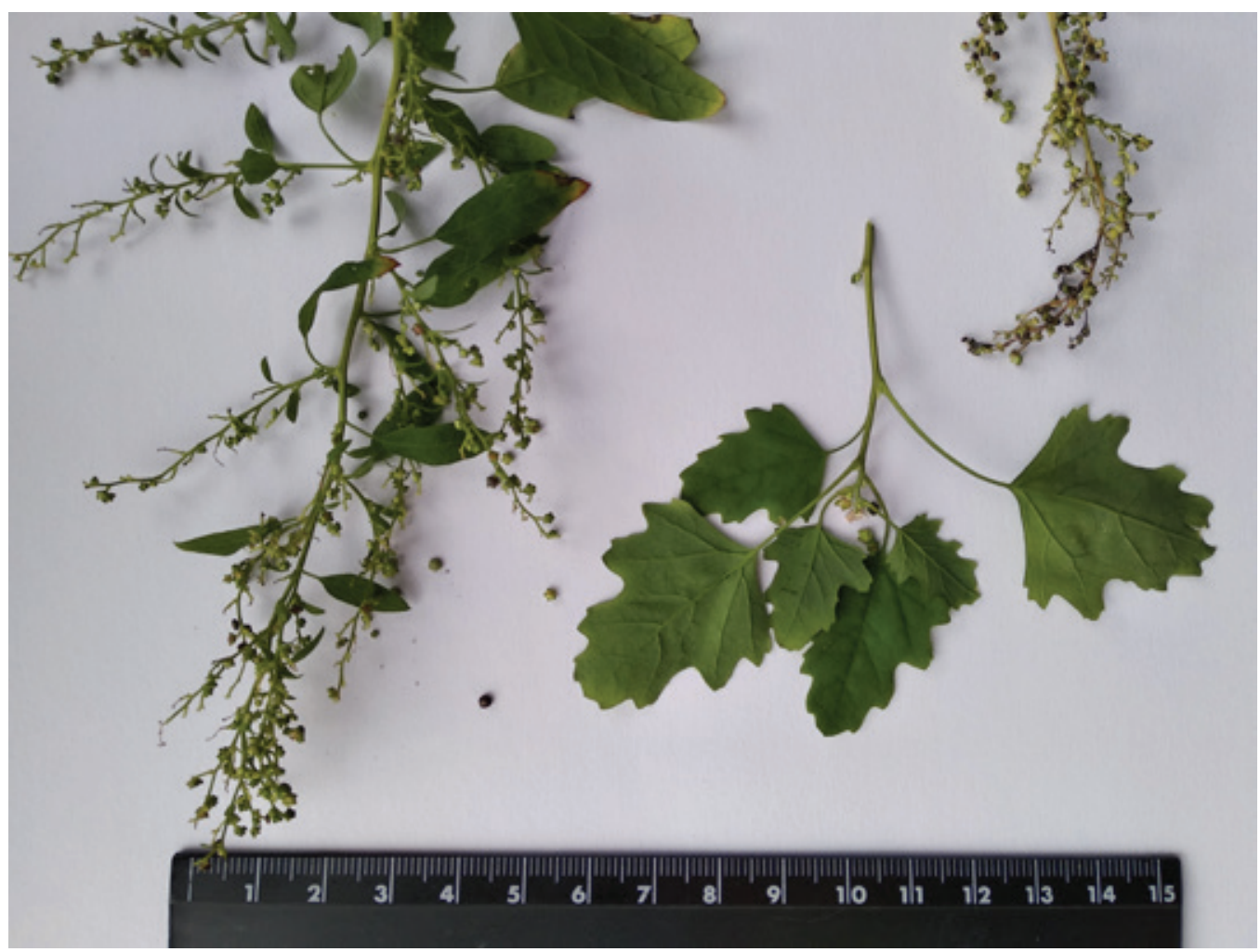

Fig. E17. Chenopodium ucrainicum - parts collected for herbarium in mid-November. Kyiv city, locus classicus, 13 November 2019 


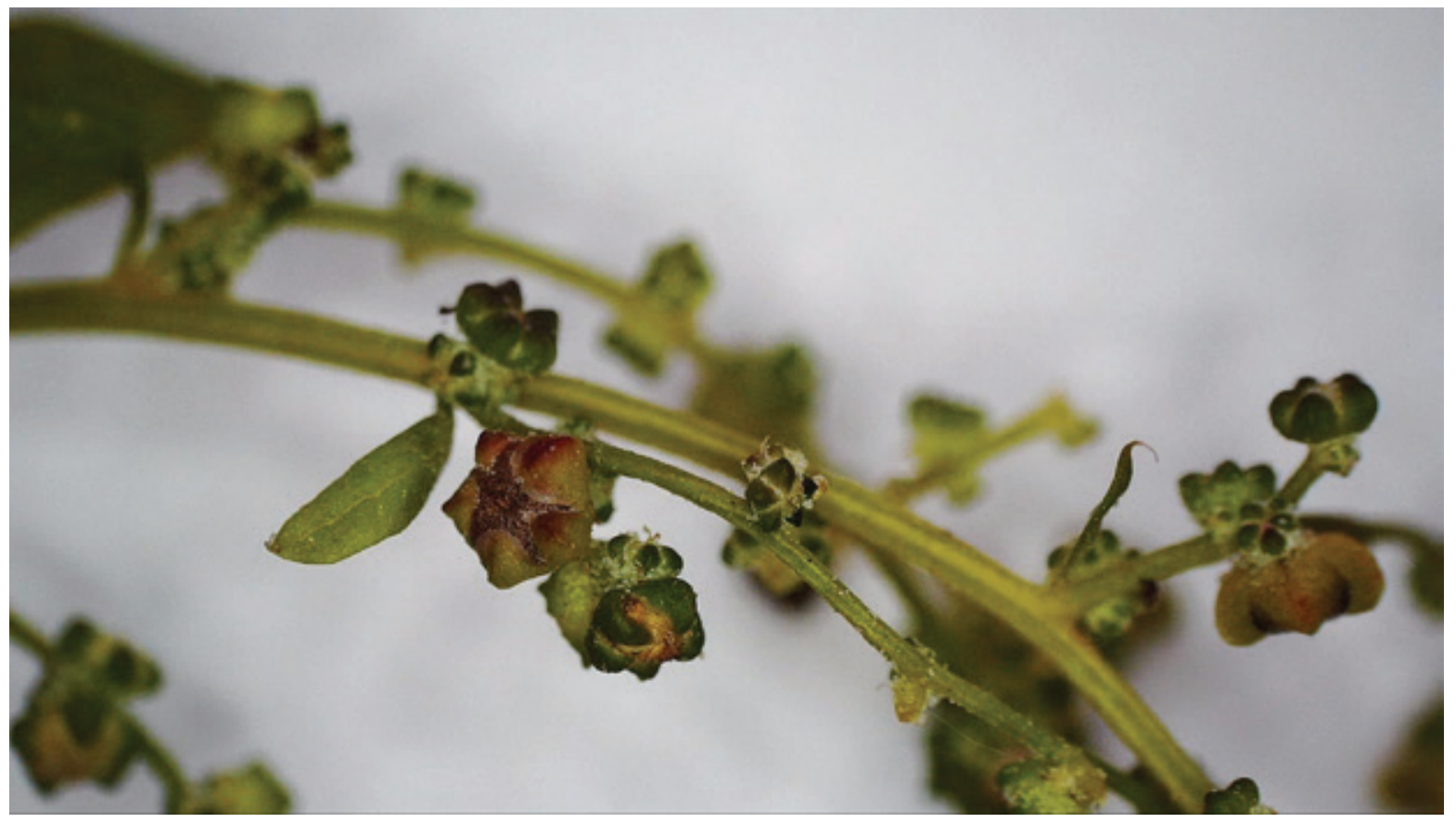

Fig. E18. Chenopodium ucrainicum: close-up of glomerules and solitary flowers in the inflorescence. 1 November 2019

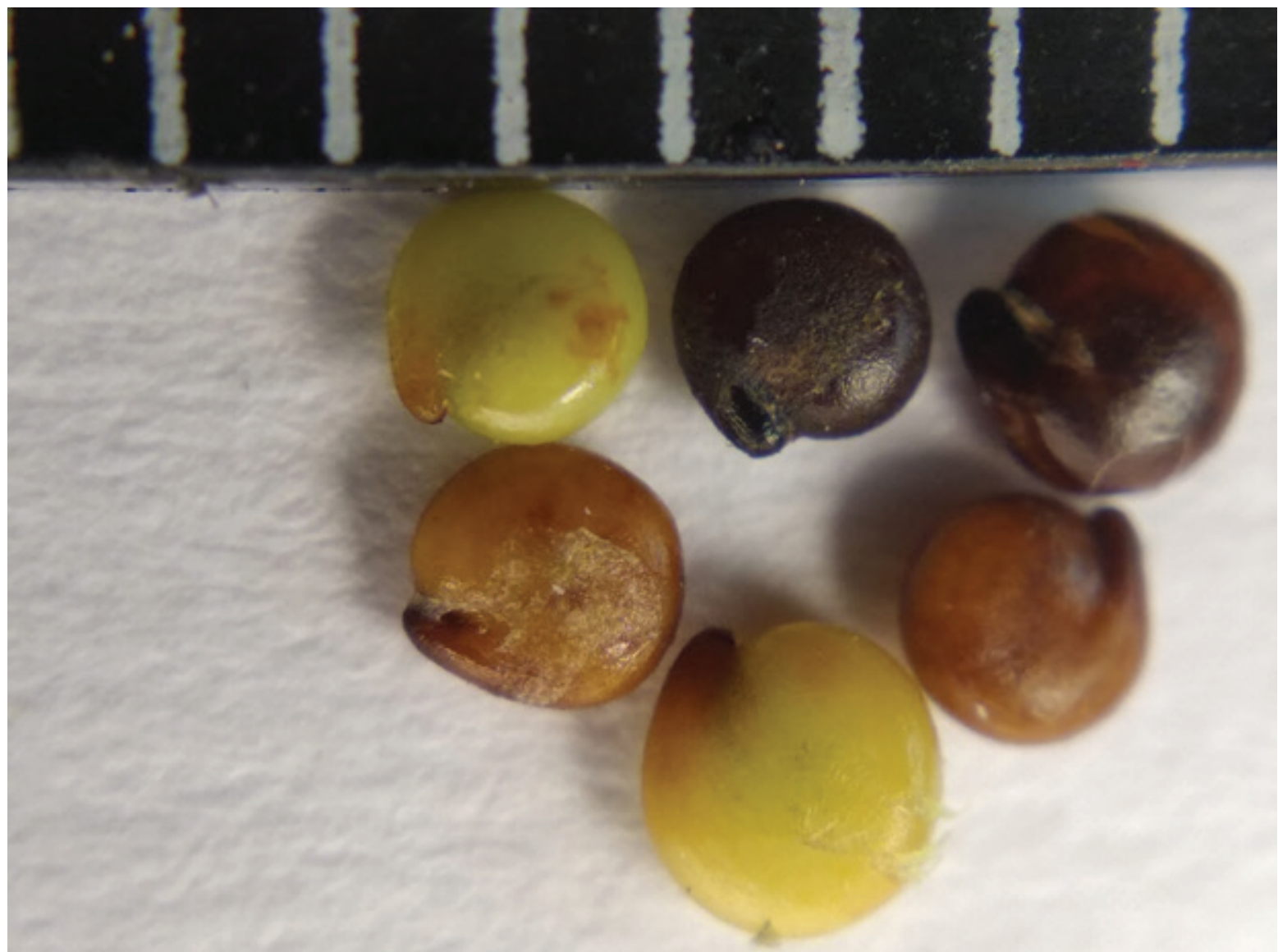

Fig. E19. Fruits/seeds from one plant of Chenopodium ucrainicum, collected in Kyiv city, locus classicus, 13 November 2019 

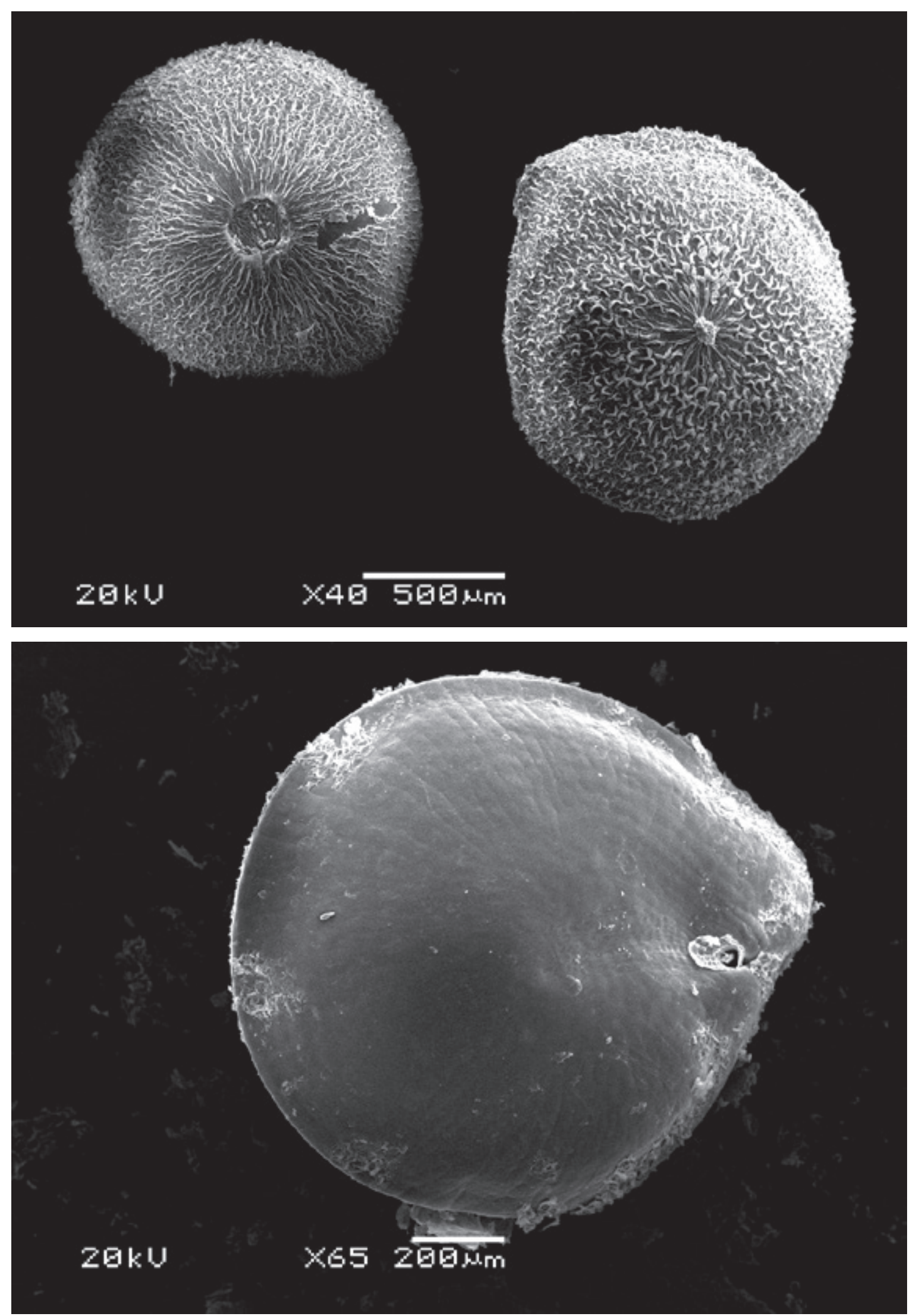

Fig. E20. A: fruits with pericarp; B: seed, pericarp removed. SEM, scale bars $500 \mu \mathrm{m}(20 \mathrm{~A})$ and $200 \mu \mathrm{m}(20 \mathrm{~B})$ 